\title{
Highly stereoselective aldol reactions by Memory of Chirality: synthesis of quaternary $\beta$-hydroxy $\alpha$-amino acids
}

\author{
Loïc Roupnel, ${ }^{a}$ Régis Guillot, ${ }^{a}$ Didier Gori, ${ }^{\mathrm{b},{ }^{\ddagger}}$ Baby Viswambharan, ${ }^{\mathrm{b}}$ Cyrille Kouklovsky, ${ }^{\mathrm{b}}$ and Valérie
} Alezra*,b

${ }^{a}$ Institut de Chimie Moléculaire et des Matériaux d'Orsay - Services communs, CNRS, UMR 8182, Université Paris-Saclay, 91405 Orsay, France

${ }^{\mathrm{b}}$ Institut de Chimie Moléculaire et des Matériaux d'Orsay - Méthodologie, Synthèse et Molécules Thérapeutiques, CNRS, UMR 8182, Université Paris-Saclay, 91405 Orsay, France, valerie.alezra@universite-paris-saclay.fr

We describe here an asymmetric aldol reaction based on the principle of Memory of Chirality. From $\alpha$-amino acids such as leucine and methionine, we have synthesized in 2 steps quaternary $\alpha$-amino acid derivatives with high diastereoselectivity and enantioselectivity, using the chirality of the initial $\alpha$-amino acid as the only chirality source. Furthermore, we were able to determine the relative and absolute configurations of the aldol products thanks to crystallographic structures and thus showed that the relative configuration depended on the aldehyde employed. We proposed a stereoselectivity explanation and obtained also quaternary $\beta$-hydroxy $\alpha$-amino acids after acidic hydrolysis.

Keywords: Amino acid $\bullet$ Memory of Chirality $\bullet$ Aldol reaction $\bullet$ asymmetric synthesis $\bullet$ Tertiary Aromatic Amide

${ }^{\ddagger}$ Current address: Aix Marseille University - CNRS, UMR7376, Laboratory of Environnemental Chemistry, 13331 Marseille, France. 


\section{Introduction}

Quaternary $\alpha$-amino acids are very interesting compounds for their proven or potential biological activities. Examples of biologically active quaternary $\alpha$-amino acids are antibiotics, such as peptaibols, ${ }^{[1]}$ antihypertensive drug such as methyIDOPA or among $\beta$-hydroxy $\alpha$-amino acids, ${ }^{[2]}$ lactacystin, kaitocephalin, calcaridine $A$ or sphingofungins which have potent antifungal activities.... They are also found in peptide chemistry, because the presence of the quaternary center induces a conformational change, even a flexibility decrease of the structure, while increasing its metabolic stability. ${ }^{[3]}$ They can furthermore be used as reaction intermediates, as in the synthesis of (-)-Penibruguieramine $A .{ }^{[4,5]}$ Because of their multiple interests, many ways to access quaternary $\alpha$-amino acids have been developed. ${ }^{[6-10]}$ Among these, methods based on the principle of memory of chirality $(\mathrm{MOC})^{[11-24]}$ use as the only source of chirality the chirality of a natural $\alpha$ amino acid, the initial reactant, although it disappears transiently during the reaction. Our group has been interested for many years in the development of asymmetric syntheses based on this principle. We have developed a synthesis of quaternary $\alpha$-amino acids by alkylation in only 3 steps $^{[25,26]}$ a method that we have applied to the synthesis of methyldopa ${ }^{[27]}$ and to microflow reactors. ${ }^{[28]}$ We also extended this strategy to oxidative coupling of enolate ${ }^{[29]}$ and to the aldol reaction of alanine derivatives. ${ }^{\left[{ }^{30]}\right.}$ In the latter case, we have been able to demonstrate a control of the second asymmetric center by the nature of the aromatic aldehyde used (Scheme 1). We wanted to know if this control was specific to the alanine derivative or was also valid for other amino acids. We present here our latest results concerning this $\mathrm{MOC}$ aldol reaction applied to other amino acids and thanks to some crystallographic structures of some major diastereomers, we were able to confirm the dependence of the configuration of the second center with the nature of the aldehyde.
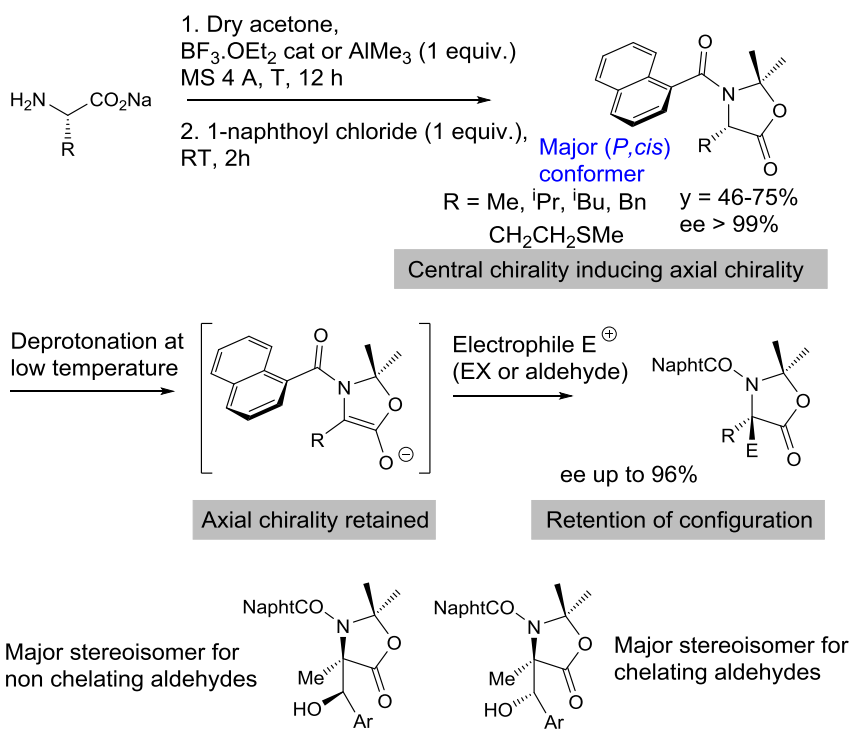

Relative configuration for aldol reaction on alanine derivative

Scheme 1. Previous results for alkylation and aldol reactions by Memory of Chirality.

\section{Results and Discussion}

We targeted mainly two amino acids, leucine, which showed good results in alkylation reactions and methionine, as an example of functionalized amino acid. According to our previous strategy, an oxazolidinone is formed without racemization in a single step from the sodium salt of the corresponding $\alpha$-amino acid, acetone and naphthoyl chloride. The presence of a tertiary aromatic amide function in the compound thus formed induces the creation of a dynamic axial 
chirality (these compounds are not planar and possess two slow rotations, the Ar-CO and the N-CO rotations). The preferred orientation of the naphthyl group is on the same side as the amino acid residue (major $(P, c i s)$ conformer) and it allows to preserve, at low temperature, the chiral information during the planar enolate formation step. This major conformer thus induces a stereoselective approach of the electrophile (whether it is an alkyl group or an aldehyde) by the face opposite to the naphthyl group, leading to a global retention of configuration for the initial asymmetric center (scheme 1). It should be noted here that the major $(P$, cis) conformer is not the only one present but that we probably have a dynamic kinetic resolution.

We thus synthesized the corresponding oxazolidinones and used the reaction conditions developed for the aldol reaction of alanine: mixing of the aromatic aldehyde with the oxazolidinone (at room temperature or low temperature), then slow addition at $-78^{\circ} \mathrm{C}$ of the base - KHMDS (over 2 minutes) - to avoid racemization due to heating of the medium; treatment of the reaction at $-78{ }^{\circ} \mathrm{C}$ with a $5 \%$ aqueous $\mathrm{NaHCO}_{3}$ solution to avoid hydrolysis of the oxazolidinone as well as retro-aldol reaction. For leucine derivative $\mathbf{1}-\mathbf{A}$, we tested two types of conditions: a sequential reaction (deprotonation for $t_{1}$ minutes and then addition of the aldehyde) and an in situ reaction (mixing the aldehyde with the oxazolidinone at room temperature, before lowering the temperature to $-78^{\circ} \mathrm{C}$ to perform the deprotonation). The results are collected in Table 1. It appears that the aldol reaction takes place in all cases with very good diastereomeric ratios, better than those observed for the alanine derivative (the assignments of the relative configuration were based on crystallographic structures of major diastereomer of some aldol products - see below for determination and stereoselectivity explanation). The enantiomeric excesses are higher than $70 \%$ in the optimized reactions and can go up to enantiopure compounds, as in the case of compound 3 (the enantiomeric excess can also be improved by recrystallization, entry 7). We did not need to replace THF with the ether/DME mixture that had been used for the alkylation reactions. In general, it is better to perform the reaction in situ, to obtain better enantiomeric excesses (entries 1 and 4 or 9 and 11). This probably limits the racemization of the enolate, which is trapped directly by the aldehyde. Some aldol products, such as the 3-pyridine compound have a tendency to degrade rapidly, so it is sometimes simpler to acetylate them for purification (yield are in this case calculated on compound Ac-4, on 2 steps). The change in the amount of THF does not have a great influence (entries 1-3) and the introduction of the aldehyde at $-78^{\circ} \mathrm{C}$ (entries 6 and 10) generally induces a decrease in yield, probably due to a decrease in its solubility and consequently to a less homogeneous mixture.

Table 1. Aldol reaction with Leucine oxazolidinone 1-A (in situ or sequential procedure) ${ }^{[a]}$

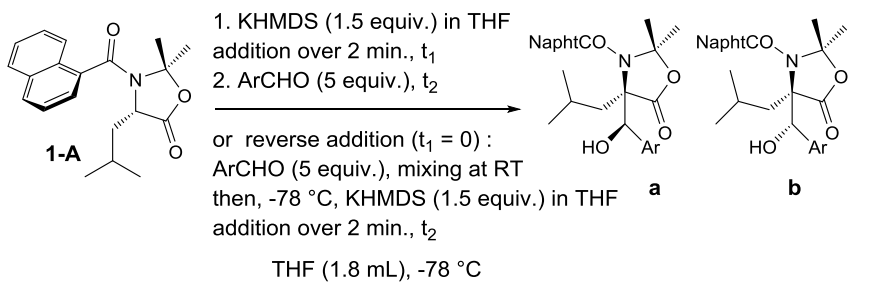

\begin{tabular}{|c|c|c|c|c|c|c|}
\hline Entry & $\mathrm{ArCHO}$ & $\begin{array}{l}t_{1} / t_{2} \\
(\min .)\end{array}$ & Comp. & $\mathrm{dr}^{[\mathrm{b}]}$ & $e^{[c]}(\%)$ & $\begin{array}{l}\text { yield }^{[\mathrm{d}]} \\
(\%)\end{array}$ \\
\hline 1 & $\begin{array}{l}m-\mathrm{Br}- \\
\mathrm{C}_{6} \mathrm{H}_{4} \mathrm{CHO}\end{array}$ & $8 / 10$ & 2 & $>99: 1$ & $69 /-$ & 92 \\
\hline $2^{[e]}$ & $\begin{array}{l}m-\mathrm{Br}- \\
\mathrm{C}_{6} \mathrm{H}_{4} \mathrm{CHO}\end{array}$ & $8 / 10$ & 2 & $>99: 1$ & $64 /-$ & 63 \\
\hline $3^{[f]}$ & $\begin{array}{l}m-\mathrm{Br}- \\
\mathrm{C}_{6} \mathrm{H}_{4} \mathrm{CHO}\end{array}$ & $8 / 10$ & 2 & $>99: 1$ & $59 /-$ & 84 \\
\hline 4 & $m-\mathrm{Br}-$ & o/18 & 2 & $>99: 1$ & $72 /-$ & 95 \\
\hline
\end{tabular}




\section{$\mathrm{C}_{6} \mathrm{H}_{4} \mathrm{CHO}$}

\begin{tabular}{|c|c|c|c|c|c|c|}
\hline 5 & $\begin{array}{l}\text { 2-pyridine- } \\
\text { CHO }\end{array}$ & $0 / 18$ & $3^{[g]}$ & $4: 96$ & $>99 />99$ & 56 \\
\hline $6^{[\mathrm{h}]}$ & $\begin{array}{l}\text { 3-pyridine- } \\
\mathrm{CHO}\end{array}$ & $0 / 12$ & Ac- 4 & $>99: 1$ & 48/- & $48^{[i]}$ \\
\hline 7 & $\begin{array}{l}\text { 3-pyridine- } \\
\mathrm{CHO}\end{array}$ & $0 / 12$ & Ac- 4 & $>99: 1$ & $76^{[\mathrm{j}]} /-$ & $55^{[\mathrm{i}]}$ \\
\hline $8^{[\mathrm{k}]}$ & $\begin{array}{l}\text { 3-pyridine- } \\
\mathrm{CHO}\end{array}$ & $0 / 12$ & Ac- 4 & $>99: 1$ & $80 /-$ & $3^{[i]}$ \\
\hline 9 & $o-\mathrm{F}-\mathrm{C}_{6} \mathrm{H}_{4} \mathrm{CHO}$ & $8 / 10$ & 5 & $97: 3$ & $67 / 59$ & 60 \\
\hline $10^{[\mathrm{h}]}$ & $o-\mathrm{F}-\mathrm{C}_{6} \mathrm{H}_{4} \mathrm{CHO}$ & $0 / 18$ & $5^{[l]}$ & $>99: 1$ & $82 /-$ & 61 \\
\hline 11 & $\mathrm{o}-\mathrm{F}-\mathrm{C}_{6} \mathrm{H}_{4} \mathrm{CHO}$ & $0 / 18$ & 5 & $96: 4$ & $82 / 86$ & 81 \\
\hline
\end{tabular}

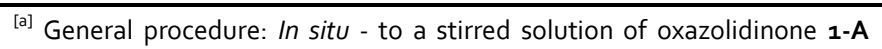
(100 mg) and aldehyde (5 equiv) in THF ( $1.8 \mathrm{~mL}$ ) cooled to $-78^{\circ} \mathrm{C}$ was added a solution of KHMDS (1.5 equiv) in THF dropwise (over $2 \mathrm{~min}$.) and the mixture was stirred for $t_{2} \min$. at $-78^{\circ} \mathrm{C}$; sequential - Identical to in situ procedure, except that KHMDS is added first and aldehyde is then added after $t_{1} \min$. Unless specified, absolute and relative configurations were assumed by analogy. ${ }^{[b]}$ ratio a: b determined by chiral stationary-phase HPLC on the crude product. ${ }^{[c]}$ ee of $\mathbf{a} / \mathbf{b}$ determined by chiral stationaryphase HPLC after purification. ${ }^{[d]}$ combined yield of $\mathbf{a}$ and $\mathbf{b} .{ }^{[\mathrm{e}]}$ THF volume $1.2 \mathrm{~mL}$ instead of $1.8 \mathrm{~mL}$. ${ }^{[\mathrm{f}]} \mathrm{THF}$ volume $2.4 \mathrm{~mL}$ instead of $1.8 \mathrm{~mL}$. ${ }^{[\mathrm{g}}$ Absolute configuration of major diastereomer $\mathbf{3 b}$ was assigned by X-Ray crystallography. ${ }^{[\mathrm{h}]}$ aldehyde was added at $-78^{\circ} \mathrm{C}$ instead of RT. ${ }^{[i]}$ yield calculated after acetylation on 2 steps. ${ }^{[j]}$ ee $=91 \%$ after recrystallization. ${ }^{[k]}$ only 1 equiv of KHMDS was used. ${ }^{[1]}$ Absolute configuration of major diastereomer $\mathbf{5}$ a was assigned after acetylation by X-Ray crystallography.

On the methionine derivative 1-B, we also tested various aromatic aldehydes and the results are collected in Table 2 . We applied only the in situ conditions, the aldehyde being introduced prior to the base, either at RT or at $-78^{\circ} \mathrm{C}$ depending on the case. By default, the aldehyde was added at $-78^{\circ} \mathrm{C}$. However, when the enantiomeric excesses were low, probably due to a lack of solubility of the aldehyde, it was then introduced at room temperature and the mixture cooled to $-78^{\circ} \mathrm{C}$ (entries 1 and 2). The observed diastereomeric ratios are always higher than those of the alanine derivative. The enantiomeric excesses are generally higher than $70 \%$, except in the disappointing case of ortho-bromobenzaldehyde (entries 3-6). For the latter, replacing THF with ether or decreasing the number of aldehyde equivalents did not result in a better enantiomeric excess (entries 5 and 6). For 3-pyridine-carboxaldehyde, the enantiomeric excess could be improved by decreasing the amount of base employed and addition of the aldehyde at room temperature (entries 11 and 12). Changing the reaction time does not have a significant influence on the enantiomeric excess (entries 7 and 8, or 9 and 10). Again, the best enantiomeric excess was obtained with 2-pyridine carboxaldehyde ( $97 \%$ ee for the major diastereomer, entry 7 ).

Table 2. Aldol reaction with Methionine oxazolidinone 1-B (in situ procedure) ${ }^{[\mathrm{a}]}$

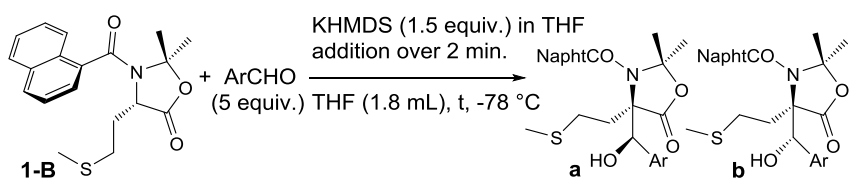




\begin{tabular}{|c|c|c|c|c|c|c|c|}
\hline Entry & $\mathrm{ArCHO}$ & $\begin{array}{l}\mathrm{T}^{[\mathrm{b}]} \\
\left({ }^{\circ} \mathrm{C}\right)\end{array}$ & $\begin{array}{l}\mathrm{t} \\
\text { (min.) }\end{array}$ & Com & $\mathbf{d r}^{[c]}$ & $\begin{array}{l}e e^{[d]} \\
(\%)\end{array}$ & $\begin{array}{l}\text { yield }^{[\mathrm{e}} \\
(\%)\end{array}$ \\
\hline 1 & $m-\mathrm{Br}-\mathrm{C}_{6} \mathrm{H}_{4} \mathrm{CHO}$ & -78 & 10 & 6 & $>99: 1$ & $30 /-$ & 42 \\
\hline 2 & $m-\mathrm{Br}-\mathrm{C}_{6} \mathrm{H}_{4} \mathrm{CHO}$ & $\mathrm{RT}$ & 10 & 6 & $>99: 1$ & $73 /-$ & 65 \\
\hline 3 & $0-\mathrm{Br}-\mathrm{C}_{6} \mathrm{H}_{4} \mathrm{CHO}$ & RT & 18 & 7 & $87: 13$ & $61 / 89$ & $30^{[f]}$ \\
\hline 4 & $o-\mathrm{Br}-\mathrm{C}_{6} \mathrm{H}_{4} \mathrm{CHO}$ & $\mathrm{RT}$ & 12 & 7 & $>99: 1$ & $60 /-$ & 72 \\
\hline $5^{[\mathrm{g}]}$ & $\mathrm{O}-\mathrm{Br}-\mathrm{C}_{6} \mathrm{H}_{4} \mathrm{CHO}$ & $\mathrm{RT}$ & 18 & 7 & $>99: 1$ & $60 /-$ & 50 \\
\hline $6^{[\mathrm{h}]}$ & $0-\mathrm{Br}-\mathrm{C}_{6} \mathrm{H}_{4} \mathrm{CHO}$ & RT & 12 & 7 & $98: 2$ & $50 /-$ & 73 \\
\hline 7 & 2-pyridine-CHO & -78 & 15 & $8^{[i]}$ & $15: 85$ & $82 / 97$ & 65 \\
\hline 8 & 2-pyridine-CHO & -78 & 12 & 8 & $17: 83$ & $89 / 98$ & 65 \\
\hline 9 & $o-\mathrm{F}-\mathrm{C}_{6} \mathrm{H}_{4} \mathrm{CHO}$ & -78 & 18 & 9 & $>99: 1$ & $85 /-$ & 99 \\
\hline 10 & $o-\mathrm{F}-\mathrm{C}_{6} \mathrm{H}_{4} \mathrm{CHO}$ & -78 & 12 & 9 & $>99: 1$ & 81/- & 92 \\
\hline 11 & 3-pyridine-CHO & -78 & 12 & 10 & $98: 2$ & $47 /-$ & 80 \\
\hline $12^{[j]}$ & 3-pyridine-CHO & RT & 12 & 10 & $98: 2$ & $75 /-$ & 88 \\
\hline \multicolumn{8}{|c|}{ and aldehyde ( 5 equiv) in $\operatorname{THF}\left(1.8 \mathrm{~mL}\right.$ ) at $-78^{\circ} \mathrm{C}$ was added a solution of } \\
\hline \multirow{6}{*}{\multicolumn{8}{|c|}{$\begin{array}{l}\text { KHMDS ( } 1.5 \text { equiv) in THF dropwise (over } 2 \text { min.) and the mixture was } \\
\text { stirred for t min. at }-78^{\circ} \mathrm{C} .{ }^{[b]} \text { temperature at which the aldehyde is added } \\
\text { to the oxazolidinone. Unless specified, absolute and relative } \\
\text { configurations were assumed by analogy. }{ }^{[c]} \text { ratio a: b determined by } \\
\text { chiral stationary-phase HPLC on the crude product. }{ }^{[d]} \text { ee of a/b } \\
\text { determined by chiral stationary-phase HPLC after purification. }{ }^{[e]} \\
\text { combined yield of a and } b .{ }^{[f]} \text { diastereomers are difficult to separate. }{ }^{[g]} \\
\text { diethyl ether was used instead of THF. }{ }^{[h]} \text { Only } 3 \text { equiv of aldehyde were }\end{array}$}} \\
\hline & & & & & & & \\
\hline & & & & & & & \\
\hline & & & & & & & \\
\hline & & & & & & & \\
\hline & & & & & & & \\
\hline \multicolumn{8}{|c|}{ used. ${ }^{[i]}$ Absolute configuration of major diastereomer $\mathbf{8 b}$ was assigned by } \\
\hline \multicolumn{8}{|c|}{ X-Ray crystallography. ${ }^{[j]}$ only 1 equiv of KHMDS was used. } \\
\hline
\end{tabular}

Consequently, we wanted to test the aldol reaction with 2-pyridine carboxaldehyde on oxazolidinones derived from other amino acids. We thus tested the valine and phenyl alanine derivatives (Table 3 ). The valine derivative $1-C$ leads to the expected compound with high diastereomeric ratio and enantiomeric excess for the major diastereomer. In the case of phenylalanine 1-D, we directly acetylated the reaction product for ease of purification and product stability. The result was very disappointing, the diastereomeric ratio and enantiomeric excesses being both low. This derivative was the one that already gave the worst results in the alkylation reactions. The presence of the benzyl group disturbs the conformer proportions observed in NMR at low temperature (in THF, there was a $(P, c i s) /(M, c i s)$ conformer ratio of $100 / 50$ for this derivative, compared to $100 / 29$ for alanine and especially a cis/trans conformer ratio of 100/9 compared to $100 / 2$ in the case of alanine) and this probably impairs the selectivity. ${ }^{[25]}$ This is likely to be even more pronounced for aldol reactions, as the aldehyde is an aromatic aldehyde, which can also interact with the benzyl group. We also tested 2-fluorobenzaldehyde on phenylalanine but the enantiomeric excess was only $34 \%$ (compound 13a was obtained with a very good diastereomeric ratio of $98: 2$ and a yield of $52 \%$ ). In all cases (except for the particular case of phenylalanine), the observed enantiomeric excesses are comparable to those obtained during alkylation reactions. When the enantiomeric excess is lower, this is probably due to a decrease in the reactivity of the aldehyde, as in the case of ortho-bromobenzaldehyde, which is likely 
too hindered, or in the case of poorly soluble aldehydes added at $-78^{\circ} \mathrm{C}$ (entry 6 , table 1 and entry 1 , table 2 ). Thus, the enantiomeric excess is presumably kinetically controlled and not compromised by retro aldol reaction and subsequent enolate racemization.

Table 3. Aldol reaction with oxazolidinones 1 with 2-pyridine carboxaldehyde ${ }^{[a]}$

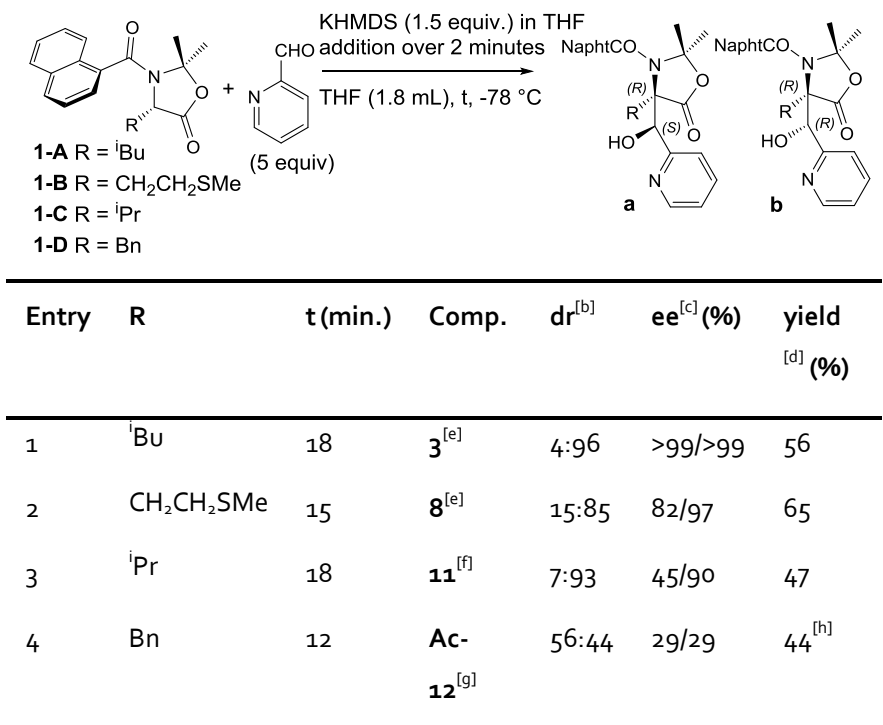

\footnotetext{
${ }^{[a]}$ General procedure: to a stirred solution of oxazolidinone 1-A (100 $\mathrm{mg}$ ) and aldehyde ( 5 equiv) in THF ( $1.8 \mathrm{~mL}$ ) cooled to $-78^{\circ} \mathrm{C}$ was added a solution of KHMDS (1.5 equiv) in THF dropwise (over 2 min.) and the mixture was stirred for $t_{2}$ min. at $-78^{\circ} \mathrm{C}$. ${ }^{[b]}$ ratio $a: b$ determined by chiral stationary-phase HPLC on the crude product. ${ }^{[c]}$ ee of $\mathbf{a} / \mathbf{b}$ determined by chiral stationary-phase HPLC after purification. ${ }^{[d]}$ combined yield of a and $\mathbf{b} .{ }^{\left[{ }^{[e]}\right.}$ Absolute configuration of major diastereomers $\mathbf{3} \mathbf{b}$ and $\mathbf{8} \mathbf{b}$ were assigned by $\mathrm{X}$-Ray crystallography. ${ }^{[f]}$ Absolute and relative configuration of major diastereomer 11a were assumed by analogy. ${ }^{[g]}$ Relative configuration of major diastereomer Ac-12a was assigned by X-Ray crystallography. ${ }^{\text {[h] }}$ yield calculated after acetylation on 2 steps.
}

Regarding the control of the relative configuration of the aldol product by the substrate, we were able to obtain crystallographic structures on major diastereomer of some aldol products and thus to have access to the relative and possibly absolute configuration (when the latter is accessible, we observe, as expected, the retention of configuration of the initial $\alpha$-amino acid). The crystallographic structure of the compounds $\mathbf{3} \mathbf{b}$ and $\mathbf{8} \mathbf{b}$ thus shows that the relative configuration is identical to that obtained in the case of the reaction of oxazolidinone derived from alanine with furan-2carboxaldehyde (we had not performed the aldol reaction of the alanine derivative with 2-pyridine-carboxaldehyde). In the case of the phenylalanine derivative (crystallographic structure of acetylated major diastereoisomer Ac-12a), the relative configuration of the major diastereomer does not correspond to that observed for the leucine and methionine derivatives 3b and $\mathbf{8 b}$. However, this does not seem significant to US, as the diastereomeric ratio is close to 1:1. Thus, when 2pyridinecarboxaldehyde is used, there is probably complexation of the potassium enolate by the pyridine nitrogen (pyridine, a good complexing agent, is regularly used to achieve a better control of the stereoselectivity ${ }^{[31]}$ ) as in transition state II (scheme 2). More surprisingly, the crystallographic structure of the acetylated compound Ac-5a is different from that observed for the major diastereomer in the reaction with the alanine derivative. Therefore, there is probably no complexation with fluorine in this case. It can consequently be assumed that for all compounds resulting from aldol 
reaction with an aldehyde different from 2-pyridinecarboxaldehyde, the absolute configuration of the new asymmetric center created is identical (major diastereomer a). This corresponds to an aldol product controlled by a classical Zimmerman-Traxler transition state (transition state l, scheme 2). There is thus a control of the second asymmetric center by the aldehyde, phenomenon to our knowledge not described in the literature (except in our previous publication).
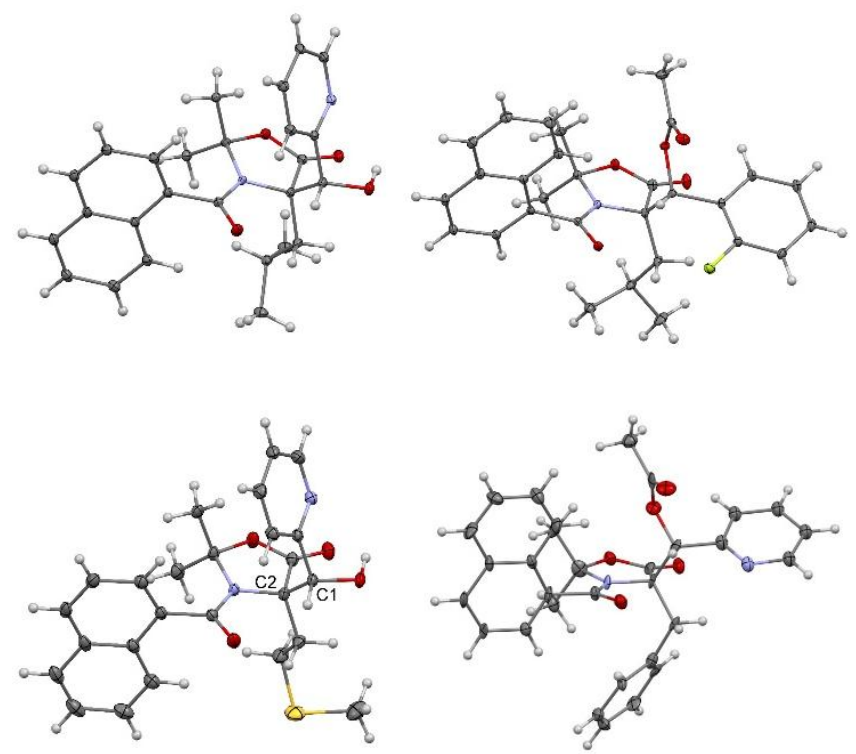

Figure 1. Crystallographic structures of compounds 3b (up left), Ac-5a (up right), 8b (bottom left), Ac-12a (bottom right, racemic).
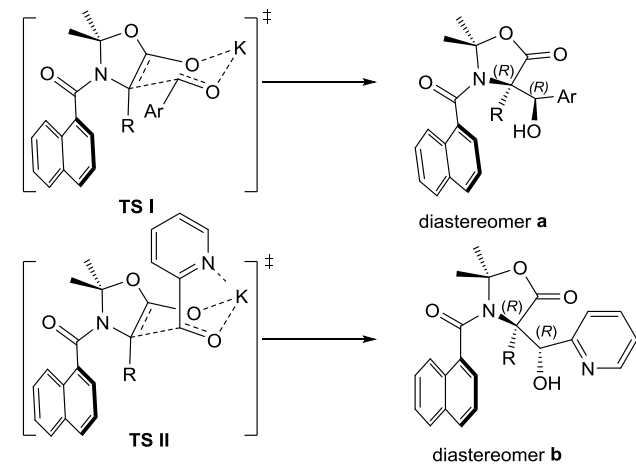

Scheme 2. Proposed transition state for stereoselectivity explanation: with most aldehydes (up) and with 2-pyridine carboxaldehyde (bottom).

The next step was the hydrolysis of the aldol products. This was performed on the products after acetylation, to avoid any problem of degradation of the aldol compounds. We applied the conditions developed previously in the laboratory (heating in a mixture of $6 \mathrm{~N}$ hydrochloric acid and acetic acid) and obtained for leucine derivatives Ac-4a and Ac-5a the expected amino acids hydrochloride $\mathbf{1 4}$ and $\mathbf{1 5}$ (scheme 3). On the other hand, for methionine derivatives (on the compound resulting from the reaction with 2 -fluorobenzaldehyde 9 a after acetylation), we observed the formation of a cyclic product 16, whose sulfur is de-methylated, which we were able to characterize by NMR (proton, carbon, HSOC) and mass, but which we were unfortunately unable to isolate in pure form. This type of cyclization has already been described in the past. ${ }^{\left[{ }^{22]}\right.}$ We could consider deprotecting the methionine derivatives using milder conditions, as we described in the case of frozen chirality (basic hydrolysis of oxazolidinone, esterification of the acid, then reduction of the amide to imine by Schwartz's reagent and mild hydrolysis) ${ }_{1}^{[33,34]}$ in order to retain the methyl group. This is currently under investigation. 


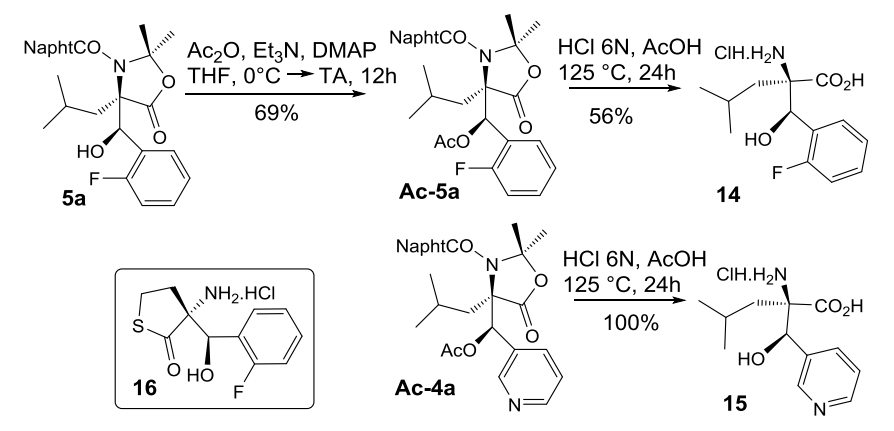

Scheme 3. Hydrolysis of diastereopure acylated aldol compounds.

\section{Conclusions}

In conclusion, we extended the aldol reaction by Memory of Chirality that we had previously developed to other amino acids. We observed better diastereoselectivity and good enantiomeric excesses. In the best case, we were able to obtain the compound $\mathbf{3} \mathbf{b}$ in enantiopure form. We also showed that there was a control of the second asymmetric center which depended on the nature of the aldehyde employed. $\beta$-hydroxy $\alpha$-amino acids were synthesized efficiently from leucine. The application of this strategy to the total synthesis of active molecules is under study in our laboratory.

\section{Experimental Section}

\section{General Information}

Unless otherwise stated, all reactions were conducted in oven dried glassware under an atmosphere of dry argon gas. THF was distilled over sodium/benzophenone under argon. Acetone was purchased with water $<50 \mathrm{ppm}$. All other reagents were used as received. Potassium bis(trimethylsilyl)amide was used as a THF solution (1 M). Flash chromatography was performed on Kieselgel $60(35-70 \mu \mathrm{m})$ silica gel. Infrared spectra were recorded as thin films on $\mathrm{NaCl}$ plates using an FT-IR spectrophotometer. ${ }^{1} \mathrm{H}$ NMR spectra were measured at 250, 300, 360 or $400 \mathrm{MHz}$ using $\mathrm{CDCl}_{3}, \mathrm{MeOD}_{1} \mathrm{C}_{6} \mathrm{D}_{6}$, toluene, $\mathrm{CD}_{2} \mathrm{Cl}_{2}$ or $\mathrm{D}_{2} \mathrm{O}$ as solvent. Chemical shifts are reported in $\delta$ units to $0.01 \mathrm{ppm}$ precision with coupling constants reported to $0.1 \mathrm{~Hz}$ precision using residual solvent as an internal reference. Multiplicities are reported as follows: $s=\operatorname{singlet}, d=$ doublet, $\mathrm{t}=$ triplet, $\mathrm{q}=$ quadruplet, $\mathrm{m}=$ multiplet, $\mathrm{bs}=$ broad singlet, $\mathrm{bd}=$ broad doublet. ${ }^{13} \mathrm{C}$ NMR spectra were measured at $62.5,75$, 90 or $100 \mathrm{MHz}$ using $C D \mathrm{Cl}_{3}, \mathrm{MeOD}, \mathrm{CD}_{2} \mathrm{Cl}_{2}$ or $\mathrm{D}_{2} \mathrm{O}$ as solvent. Chemical shifts are reported in $\delta$ units to $0.1 \mathrm{ppm}$ precision using residual solvent as an internal reference. Mass spectra were measured on a ESI Q-Tof mass spectrometer Bruker at the Institut de Chimie Moléculaire et des Matériaux (ICMMO) Mass Spectrometry Laboratory. HPLC analyses were performed on Dionex instrument (Ultimate 3000) in our laboratory. This instrument is principally composed of gradient pump, a columns selector valve, Peltier effect column oven and Diodes array detector. All enantiomerics excesses were determined by normal phase HPLC analyses with four different chiral stationary phase columns:

-Daicel column, Chiralcel OJ-H ( $250 \mathrm{~mm} \times 4,6 \mathrm{~mm}$ id); part. size: $5 \mu \mathrm{m}$

-Daicel column, Chiralpak AD-H (250mm×4,6mm id); part. size: $5 \mu \mathrm{m}$

-Daicel column, Chiralpak IC (250mm×4,6mm id); part. size: $5 \mu \mathrm{m}$

-Régis column Type "Pirkle", $(\mathrm{S}, \mathrm{S})$ Whelk-O 1 (250mm×4,6mm id); part. size: $5 \mu \mathrm{m}$

Note: all the experimental procedures listed below apply to both racemic and enantiomerically pure material. All aldol reaction for racemic compounds were performed in 2 steps: first deprotonation with KHMDS at $-78{ }^{\circ} \mathrm{C}$ for 6 minutes and then addition of the aldehyde, in order to get both diastereomers. Only the preparation of chiral compounds will be reported. 
For all the compounds, there exist at least two conformers and were reported for the proton or carbon $n m r$ as major $(M)$ and the minor $(m)$.

\section{General procedure for oxazolidinone synthesis}

Procedure A: In a solution of amino acid salt (1 eq) and molecular sieves $4 \AA$ (activated in the oven) in dry acetone at $0^{\circ} \mathrm{C}$ under $\mathrm{Ar}$ was added, slowly, $\mathrm{BF}_{3} . \mathrm{Et}_{2} \mathrm{O}$ (0.06 eq). The mixture was stirred $5 \mathrm{~min}$ at $0^{\circ} \mathrm{C}$ and overnight at room temperature. Then, 1-naphthoyl chloride ( $1 \mathrm{eq}$ ) was added and the resulting solution was stirred 2 hours. The reaction was filtered through silica gel and washed twice with $\mathrm{Et}_{2} \mathrm{O}$. The solvents were concentrated and the residue was dried under vacuum. After dilution in ether and $\mathrm{CH}_{2} \mathrm{Cl}_{2}$, the organic phase was washed with saturated solution of $\mathrm{NaHCO}_{3}$ and water. The crude product was obtained after concentration.

Procedure B: In a solution of amino acid salt (1 eq) and molecular sieves $4 \AA$ (activated in the oven) in dry acetone at $0^{\circ} \mathrm{C}$ under $\mathrm{Ar}$ was added, slowly, $\mathrm{AlMe}_{3}\left(1 \mathrm{eq}, 2 \mathrm{M}\right.$ in tolvene). The mixture was stirred $5 \mathrm{~min}$ at $0^{\circ} \mathrm{C}$ and overnight at room temperature. Then, 1-naphthoyl chloride (1 eq) was added and the resulting solution was stirred 2 hours. The reaction was filtered through silica gel and washed twice with $\mathrm{Et}_{2} \mathrm{O}$. The crude product was obtained after concentration.

\section{General procedure for aldol reaction of oxazolidinone with aldehydes}

To a stirred solution of starting $\mathrm{N}$-(1-naphthoyl)-oxazolidinone in THF $(1.8 \mathrm{~mL})$ at $-78^{\circ} \mathrm{C}$ was added 5 equivalents of the aldehyde (or in case of RT aldehyde addition, aldehyde was added prior to cooling). A solution of potassium bis(trimethylsilyl)amide (1M in THF) was added dropwise over 2 minutes and the resulting mixture was stirred for desired time (total reaction time including the base addition) at $-78^{\circ} \mathrm{C}$. The reaction was then quenched by the addition of $1.0 \mathrm{~mL}$ of saturated ammonium chloride solution and diluted with $10 \mathrm{~mL}$ diethyl ether and $10 \mathrm{~mL}$ of ethyl acetate. Excess ammonium chloride was washed with $5 \mathrm{~mL}$ of $5 \%$ sodium bicarbonate solution. The aqueous layer is back extracted with 5 $\mathrm{mL}$ ethyl acetate. Combined organic layers were washed with sat. $\mathrm{NaCl}$, dried over sodium sulfate, filtered, and then concentrated to give the crude product which was then purified through column chromatography on silica gel to give the desired product.

\section{General procedure for the acetylation reaction}

To a stirred solution of $\mathrm{N}$-(1-naphthoyl)-oxazolidinone and 4-(dimethylamino)pyridine in $\mathrm{THF}$ at $0^{\circ} \mathrm{C}$ were added acetic anhydride and triethylamine. The resulting mixture was stirred for the night at room temperature. The reaction was quenched by the addition of a $2 \mathrm{M}$ of aqueous solution of hydrochloric acid. The mixture was washed with a saturated sodium bicarbonate solution and the aqueous layer was extracted with ethyl acetate. The organic layer was dried over sodium sulfate, filtered, and then concentrated to give the crude product which was then purified through column chromatography on silica gel to give the desired product.

\section{General procedure for the hydrolysis of the aldol product}

The acetylated aldol product was suspended in a mixture of acetic acid $(0.5 \mathrm{~mL})$ and $6 \mathrm{~N} \mathrm{HCl}(1 \mathrm{~mL})$ and was heated to $125^{\circ} \mathrm{C}$ for 24 hours. After cooling, the reaction mixture was then diluted with water and washed with diethyl ether. The aqueous phase was concentrated to yield 2-amino-3-hydroxy-2-isobutyl-3-arylpropanoic acid derivatives as their hydrochloride salt.

\section{(S)-3-(1-naphthoyl)-4-isobutyl-2,2-dimethyl-oxazolidin-5-one 1-A}

Following the procedure $A$, with sodium L-leucinate salt $(2.20 \mathrm{~g}, 14.38 \mathrm{mmol}), \mathrm{BF}_{3} . \mathrm{Et}_{2} \mathrm{O}$ (0.06 eq, $\left.100 \mu \mathrm{L}, 0.82 \mathrm{mmol}\right)$, and 1-naphthoyl chloride ( $1 \mathrm{eq}, 2.16 \mathrm{~mL}, 14.38 \mathrm{mmol}$ ). The residue was purified by flash column chromatography on silica gel (tolvene/ethyl acetate : $100 \%$ to 95/5) to give (S)-3-(1-naphthoyl)-4-isobutyl-2,2-dimethyl-oxazolidin-5-one 1-A (2.21 g, $49 \%$, ee>99\%). All spectroscopic data are in agreement with those previously reported. ${ }^{[25]}$ 


\section{(S)-3-(1-naphthoyl)-2,2-dimethyl-4-(2-(methylthio)ethyl)-oxazolidin-5-one 1-B}

Following the procedure $B$, with sodium L-methioninate salt $(2.46 \mathrm{~g}, 14.38 \mathrm{mmol}), \mathrm{AlMe}_{3}(1 \mathrm{eq}, 7.2 \mathrm{~mL}(2 \mathrm{M}$ in toluene), 14.38 mmol), and 1-naphthoyl chloride (1 eq, $2.16 \mathrm{~mL}, 14.38 \mathrm{mmol}$ ). The residue was purified by flash column chromatography on silica gel (cyclohexane/ethyl acetate/triethylamine: 90/10/1\%) to give (S)-3-(1-naphthoyl)-2,2dimethyl-4-(2-(methylthio)ethyl)-oxazolidin-5-one 1-B (2.25 g, 45\%, ee>99\%). All spectroscopic data are in agreement with those previously reported. ${ }^{[25]}$

\section{(S)-3-(1-naphthoyl)-4-isopropyl-2,2-dimethyloxazolidin-5-one 1-C}

Following the procedure $A$, with sodium $L$-valinate salt ( $2.00 \mathrm{~g}, 14.38 \mathrm{mmol}^{2}, \mathrm{BF}_{3} . \mathrm{Et}_{2} \mathrm{O}$ (0.06 eq, $100 \mu \mathrm{L}, 0.82 \mathrm{mmol}$ ), and 1naphthoyl chloride ( 1 eq, $2.16 \mathrm{~mL}, 14.38 \mathrm{mmol}$ ). The residue was purified by flash column chromatography on silica gel (pentane/diethyl ether: 8o/20) to give (S)-3-(1-naphthoyl)-4-isopropyl-2,2-dimethyl-oxazolidin-5-one 1-C (3.28 g, 75\%, ee>99\%). All spectroscopic data are in agreement with those previously reported. ${ }^{[25]}$

(S)-3-(1-naphthoyl)-4-benzyl-2,2-dimethyloxazolidin-5-one 1-D

Following the general procedure $B$, with sodium L-phenylalaninate salt ( $2.69 \mathrm{~g}, 14.38 \mathrm{mmol}), \mathrm{AlMe}_{3}(1 \mathrm{eq}, 7.2 \mathrm{~mL}(2 \mathrm{M}$ in toluene), $14.38 \mathrm{mmol}$ ), and 1-naphthoyl chloride (1 eq, $2.16 \mathrm{~mL}, 14.38 \mathrm{mmol}$ ). The residue was purified by flash column chromatography on silica gel (cyclohexane/ethyl acetate/triethylamine : 80/20/1\%) to give (S)-3-(1-naphthoyl)-4-benzyl2,2-dimethyloxazolidin-5-one 1-D (3.14 g, 61\%, ee>99\%). All spectroscopic data are in agreement with those previously reported. $^{[25]}$

(4R)-3-(1-naphthoyl)-4-((R)-(3-bromophenyl)(hydroxy)methyl)-4-isobutyl-2,2-dimethyloxazolidin-5-one $2 a$

Following the general procedure, (S)-3-(1-naphthoyl)-4-isobutyl-2,2-dimethyl-oxazolidin-5-one 1-A (100 mg, 0.307 mmol), 3-bromobenzaldehyde (5 eq, $1.53 \mathrm{mmol}, 180 \mu \mathrm{L}$ ) and KHMDS (1.5 eq, $0.460 \mathrm{mmol}, 460 \mu \mathrm{L}(1 \mathrm{M}$ in THF)) in THF gave (4R)-3(1-naphthoyl)-4-((S)-(3-bromophenyl)(hydroxy)methyl)-4-isobutyl-2,2-dimethyloxazolidin-5-one after 18 minutes. The crude product was then purified by column chromatography on silica gel (heptane/THF : 90/10 to 70/30) to give one diastereomer $2 \mathrm{a}$ (150 mg, 95\%, ee =72\%). HPLC analysis: $(\mathrm{S}, \mathrm{S})$ Whelk-O 1, hexane/ethanol: $90 / 10,1 \mathrm{~mL} / \mathrm{min}, \mathrm{T}=25^{\circ} \mathrm{C}, \lambda=$ $222 \mathrm{~nm}$; retention times of racemic mixture: $12.2 \mathrm{~min}$. (minor) and $17.3 \mathrm{~min}$. (major $R R$ ) ee $=72 \% .{ }^{1} \mathrm{H}-\mathrm{NMR}(360 \mathrm{MHz}, 300 \mathrm{~K}$, $\left.\mathrm{CDCl}_{3}\right)$ : Conformer ratio major $(M)$ :minor $(m)$ : 0.6: $0.4 i(\delta, \mathrm{ppm})$ : $0.42(\mathrm{~s}, 3 \mathrm{Hm}), 0.54(\mathrm{~s}, 3 \mathrm{HM}), 0.99(\mathrm{~s}, 3 \mathrm{HM}), 1.10(\mathrm{~d}, J=6.3$ $\mathrm{Hz}, 3 \mathrm{Hm}), 1.11(\mathrm{~d}, J=6.5 \mathrm{~Hz}, 3 \mathrm{HM}), 1.20(\mathrm{~d}, J=6.6 \mathrm{~Hz}, 3 \mathrm{Hm}), 1.28(\mathrm{~d}, J=6.7 \mathrm{~Hz}, 3 \mathrm{HM}), 1.43(\mathrm{~s}, 3 \mathrm{Hm}), 1.94-2.04(\mathrm{~m}, 1 \mathrm{Hm})$, $2.09(\mathrm{dd}, J=8.6 \mathrm{~Hz}, J=14.5 \mathrm{~Hz}, 1 \mathrm{Hm}), 2.13-2.18(\mathrm{~m}, 1 \mathrm{HM}), 2.32(\mathrm{dd}, J=9.2 \mathrm{~Hz}, J=14.8 \mathrm{~Hz}, 1 \mathrm{HM}), 2.90(\mathrm{dd}, J=2.5 \mathrm{~Hz}, J=$ $14.6 \mathrm{~Hz}, 1 \mathrm{Hm}), 3.06(\mathrm{dd}, J=2.1 \mathrm{~Hz}, J=14.8 \mathrm{~Hz}, 1 \mathrm{HM}), 5.33(\mathrm{~d}, J=10.6 \mathrm{~Hz}, 1 \mathrm{HM}), 5.36(\mathrm{~d}, J=10.2 \mathrm{~Hz}, 1 \mathrm{Hm}), 6.51(\mathrm{~d}, J=10.6$ $\mathrm{Hz}, 1 \mathrm{HM}), 6.53(\mathrm{~d}, J=10.2 \mathrm{~Hz}, 1 \mathrm{Hm}), 7.28-7.42(\mathrm{~m}, 3 \mathrm{HM}+3 \mathrm{Hm}), 7.46-7.62(\mathrm{~m}, 4 \mathrm{HM}+4 \mathrm{Hm}), 7.72-7.76(\mathrm{~m}, 2 \mathrm{HM}+2 \mathrm{Hm}), 7.87-$ $7.96(\mathrm{~m}, 2 \mathrm{HM}+2 \mathrm{Hm}) .{ }^{13} \mathrm{C}-\mathrm{NMR}\left(62.9 \mathrm{MHz}, 300 \mathrm{~K}, \mathrm{CDCl}_{3}\right):(\delta, \mathrm{ppm}): 22.6 \mathrm{M}, 22.9 m, 24.5 \mathrm{M}, 24.7 m, 25.4 m, 25.5 \mathrm{M}, 28.5 \mathrm{M}$, $28.6 M+m, 30.1 m, 40.7 m, 40.8 M, 75.8 M, 76.2 m, 78.4 M+m, 96.4 M, 96.5 m, 123.1 M, 123.2 m, 123.7 m, 124.2 M, 124.4 M, 125.5 m$, 125.6M, 126.om, 126.2M, 126.4m, 126.8M, 126.9m, 127.5 M, 128.2m, 128.6m, 128.8M, 129.6M, 129.8m, 129.9M, 130.0M+m, $130.3 M+m, 130.7 m, 131.6 M+m, 132.8 M, 132.9 m, 133.2 M, 133.5 m, 143.2 m, 143.4 M, 170.8 M, 171.3 m, 171.4 m, 171.6 M$. HRMS (electrospray): Calculated for $\mathrm{C}_{27} \mathrm{H}_{28} \mathrm{BrNO}_{4}\left(\mathrm{M}+\mathrm{H}^{+}\right): 510.1274 i$ found: 510.1259 Calculated for $\mathrm{C}_{27} \mathrm{H}_{28} \mathrm{BrNO} \mathrm{Na}_{4}$ $\left(\mathrm{M}+\mathrm{Na}^{+}\right): 532.1094 ;$ found: 532.1074

\section{(4R)-3-(1-naphthoyl)-4-((R)-hydroxy(pyridin-2-yl)methyl)-4-isobutyl-2,2-dimethyloxazolidin-5-one 36}

Following the general procedure, (S)-3-(1-naphthoyl)-4-isobutyl-2,2-dimethyl-oxazolidin-5-one 1-A (10omg, $0.307 \mathrm{mmol}$ ), 2-pyridinecarboxaldehyde ( 5 eq, $1.53 \mathrm{mmol}, 146 \mu \mathrm{L}$ ) and KHMDS (1.5 eq, $0.460 \mathrm{mmol}, 460 \mu \mathrm{L}(1 \mathrm{M}$ in THF)) in THF gave (R)3-(1-naphtoyl)-4-55R)-hydroxy(pyridin-2-yl)methyl)-4-isobutyl-2,2-dimethyloxazolidin-5-one after 18 minutes. The crude product $(\mathrm{dr}=4 / 96)$ was then purified by column chromatography on silica gel (cyclohexane/ethyl acetate : $85 / 15$ to 30/70) to give diastereomer $\mathbf{3 b}$ (75 mg, 56\%, ee > 99\%). HPLC analysis: Chiralpack AD-H, hexane/ethanol: 95/5, $1 \mathrm{~mL} / \mathrm{min}, \mathrm{T}=35$ ${ }^{\circ} \mathrm{C}, \lambda=222 \mathrm{~nm}$; retention times of racemic mixture: major diastereomer $29.3 \mathrm{~min}$. and $38.1 \mathrm{~min}$. (RR). ee $=99 \%$ (minor 
diastereomer $14.6 \mathrm{~min}$. (minor) and $29.3 \mathrm{~min}$. (major) ee > 99\%). ${ }^{1} \mathrm{H}-\mathrm{NMR}$ (300 MHz, $300 \mathrm{~K}$, Tolvene- $\mathrm{d}_{8}$ ): Conformer ratio major $(M)$ :minor $(m)$ : 1.0: $0.5 ;(\delta, \mathrm{ppm}): 0.50(\mathrm{~s}, 3 \mathrm{Hm}), 0.74(\mathrm{~s}, 3 \mathrm{Hm}), 0.93(\mathrm{~s}, 3 \mathrm{HM}), 1.10(\mathrm{~s}, 3 \mathrm{HM}), 1.12-1.23(\mathrm{~m}, 6 \mathrm{HM}+6 \mathrm{Hm})$, 2.10-2.17 (m, $1 \mathrm{HM}+1 \mathrm{Hm}), 2.36-2.44(\mathrm{~m}, 1 \mathrm{HM}+1 \mathrm{Hm}), 3.12(\mathrm{dd}, J=3.3 \mathrm{~Hz}, J=13.9 \mathrm{~Hz}, 1 \mathrm{Hm}), 3.28(\mathrm{dd}, J=1.2 \mathrm{~Hz}, J=14.1 \mathrm{~Hz}$, $1 \mathrm{HM}), 5.10(\mathrm{~d}, J=8.7 \mathrm{~Hz}, 1 \mathrm{HM}), 5.19(\mathrm{bs}, 1 \mathrm{Hm}), 5.53(\mathrm{~d}, J=8.7 \mathrm{~Hz}, 1 \mathrm{HM}), 5.82(\mathrm{bs}, 1 \mathrm{Hm}), 6.56-6.64(\mathrm{~m}, 1 \mathrm{HM}+1 \mathrm{Hm}), 6.95-$ $7.52(\mathrm{~m}, 8 \mathrm{HM}+8 \mathrm{Hm}), 7.93(\mathrm{~d}, J=8.1 \mathrm{~Hz}, 1 \mathrm{HM}), 8.10(\mathrm{~d}, J=9.1 \mathrm{~Hz}, 1 \mathrm{Hm}), 8.25(\mathrm{~d}, J=5.1 \mathrm{~Hz}, 1 \mathrm{HM}), 8.33(\mathrm{~d}, J=4.2 \mathrm{~Hz}, 1 \mathrm{Hm})$.

${ }^{1} \mathrm{H}-\mathrm{NMR}\left(400 \mathrm{MHz}, 300 \mathrm{~K}, \mathrm{CDCl}_{3}\right)$ : Conformer ratio major $(M)$ :minor $(m)$ : 1.0: 0.5; $(\delta, \mathrm{ppm})$ : $0.89(\mathrm{~s}, 3 \mathrm{Hm}), 1.09(\mathrm{~d}, J=6.7 \mathrm{~Hz}$, $3 \mathrm{HM}), 1.10(\mathrm{~d}, J=6.7 \mathrm{~Hz}, 3 \mathrm{Hm}), 1.14(\mathrm{~s}, 3 \mathrm{HM}), 1.17(\mathrm{~d}, J=6.7 \mathrm{~Hz}, 3 \mathrm{Hm}), 1.22(\mathrm{~d}, J=6.7 \mathrm{~Hz}, 3 \mathrm{HM}), 1.25(\mathrm{~s}, 3 \mathrm{HM}), 1.52(\mathrm{~s}, 3 \mathrm{Hm})$, 1.89-1.97 (m, $1 \mathrm{Hm}), 1.99-2.08(\mathrm{~m}, 1 \mathrm{HM}), 2.25-2.35(\mathrm{~m}, 1 \mathrm{HM}+1 \mathrm{Hm}), 3.01(\mathrm{dd}, J=3.2 \mathrm{~Hz}, J=14.2 \mathrm{~Hz}, 1 \mathrm{Hm}), 3.18(\mathrm{~d}, J=12.7$ $\mathrm{Hz}, 1 \mathrm{HM}), 5.01(\mathrm{~d}, J=9.1 \mathrm{~Hz}, 1 \mathrm{HM}), 5.06(\mathrm{~d}, J=9.0 \mathrm{~Hz}, 1 \mathrm{Hm}), 5.43(\mathrm{~d}, J=9.1 \mathrm{~Hz}, 1 \mathrm{HM}), 5.66(\mathrm{~d}, J=8.6 \mathrm{~Hz}, 1 \mathrm{Hm}), 7.29-7.36(\mathrm{~m}$, $2 \mathrm{HM}+1 \mathrm{Hm}), 7.41-7.56(\mathrm{~m}, 4 \mathrm{HM}+5 \mathrm{Hm}), 7.60(\mathrm{~d}, J=7.6 \mathrm{~Hz}, 1 \mathrm{HM}), 7.70-7.93(\mathrm{~m}, 3 \mathrm{HM}+4 \mathrm{Hm}), 8.61-8.67(\mathrm{~m}, 1 \mathrm{HM}+1 \mathrm{Hm}) .{ }^{13} \mathrm{C}-$ NMR (100 MHz, $300 \mathrm{~K}, \mathrm{CDCl}$ ): ( $\delta, \mathrm{ppm}): 22.3 \mathrm{M}, 23.1 m, 24.8 M+m, 25.0 \mathrm{M}+m, 28.7 m, 29.2 M, 29.4 M, 30.3 m, 40.1 m, 41.2 M$, $72.5 m, 72.8 M, 76.0 M, 76.4 m, 96.5 M+m, 123.4 M, 123.6 m, 123.8 M+m, 124.0 M+m, 125.0 M, 125.4 M, 125.6 m, 126.0 m$, 126.5 M+m, 127.3M, 128.4m, 128.6M, 129.8m, 130.0M*2+m*2, 133.3m, 133.4M, 134.1M, 134.3m, 136.4M+m, 148.8M+m, $157.6 \mathrm{M}, 158.2 m ， 169.0 \mathrm{M}+m, 172.4 m ， 172.7 \mathrm{M}$. HRMS (electrospray): Calculated for $\mathrm{C}_{26} \mathrm{H}_{29} \mathrm{~N}_{2} \mathrm{O}_{4}\left(\mathrm{M}+\mathrm{H}^{+}\right): 433.2122$; found: 433.2124 Calculated for $\mathrm{C}_{26} \mathrm{H}_{28} \mathrm{~N}_{2} \mathrm{NaO}_{4}\left(\mathrm{M}+\mathrm{Na}^{+}\right)$: 455.1941 ; found: 455.1946 .

(R)-((R)-3-(1-naphthoyl)-4-isobutyl-2,2-dimethyl-5-oxooxazolidin-4-yl)(pyridin-3-yl)methyl acetate Ac-4a

Following the general procedure, (S)-3-(1-naphthoyl)-4-isobutyl-2,2-dimethyl-oxazolidin-5-one 1-A (100 mg, $0.307 \mathrm{mmol}$ ), 3-pyridinecarboxaldehyde ( 5 eq, $1.53 \mathrm{mmol}, 116 \mu \mathrm{L}$ ) and $\operatorname{KHMDS}(1.5 \mathrm{eq}, 0.460 \mathrm{mmol}, 460 \mu \mathrm{L}(1 \mathrm{M}$ in THF)) in THF gave (4R)-3-(1-naphthoyl)-4-((R)-hydroxy(pyridin-3-yl)methyl)-4-isobutyl-2,2-dimethyloxazolidin-5-one 4 after 12 minutes. Following the general procedure of acetylation, (4R)-3-(1-naphthoyl)-4-((R)-hydroxy(pyridin-3-yl)methyl)-4-isobutyl-2,2dimethyloxazolidin-5-one (crude product), 4-(dimethylamino)pyridin ( $0.1 \mathrm{eq}, 0.03 \mathrm{mmol}, 4 \mathrm{mg}$ ), acetic anhydride (5 eq, $1.53 \mathrm{mmol}, 145 \mu \mathrm{L})$ and triethylamine (1 eq, $0.307 \mathrm{mmol}, 410 \mu \mathrm{L})$ in THF $(3 \mathrm{~mL})$ gave $(4 R)-((R)-3-(1$-naphthoyl)-4-isobutyl2,2-dimethyl-5-oxooxazolidin-4-yl)(pyridin-3-yl)methyl acetate after one night. The crude product was then purified by column chromatography on silica gel (cyclohexane/ethyl acetate : 6o/40) to give diastereomer Ac-4a $(80 \mathrm{mg}, 55 \%$, ee = $76 \%$, and $91 \%$ after recristallization). HPLC analysis: Chiralpak IC, hexane/ethanol: 8o/20, $1 \mathrm{~mL} / \mathrm{min}, \mathrm{T}=25^{\circ} \mathrm{C}, \lambda=222 \mathrm{~nm}$; retention times of racemic mixture: $14.0 \mathrm{~min}$. and $20.1 \mathrm{~min}$. (RS). ee $=76 \%$. ${ }^{1} \mathrm{H}-\mathrm{NMR}\left(250 \mathrm{MHz}, 300 \mathrm{~K}, \mathrm{CD}_{2} \mathrm{Cl}_{2}\right): \mathrm{Conformer}$ ratio major $(M)$ :minor $(m)$ : 0.7: 0.3 (second minor, not described 0.2); $(\delta, p p m): 1.60(\mathrm{~d}, J=6.5 \mathrm{~Hz}, 3 \mathrm{HM}), 1.77(\mathrm{~d}, J=6.7 \mathrm{~Hz}$, $3 \mathrm{HM}), 1.85(\mathrm{~d}, J=6.8 \mathrm{~Hz}, 3 \mathrm{Hm}), 1.91-1.94(\mathrm{~m}, 3 \mathrm{Hm}), 1.93(\mathrm{~s}, 3 \mathrm{HM}), 1.96(\mathrm{~s}, 3 \mathrm{Hm}), 2.42(\mathrm{~s}, 3 \mathrm{Hm}), 2.44(\mathrm{~s}, 3 \mathrm{HM}), 2.51-2.64(\mathrm{~m}$, $1 \mathrm{HM}), 2.73-2.75(\mathrm{~m}, 2 \mathrm{Hm}), 2.83(\mathrm{~d}, J=14.1 \mathrm{~Hz}, 1 \mathrm{HM}), 2.93(\mathrm{~s}, 3 \mathrm{HM}), 3.00(\mathrm{~s}, 3 \mathrm{Hm}), 3.48(\mathrm{dd}, J=2.8 \mathrm{~Hz}, J=13.8 \mathrm{~Hz}, 1 \mathrm{HM})$, $3.64(\mathrm{dd}, J=1.4 \mathrm{~Hz}, J=13.7 \mathrm{~Hz}, 1 \mathrm{Hm}), 7.58(\mathrm{~s}, 1 \mathrm{Hm}), 7.83(\mathrm{~s}, 1 \mathrm{HM}), 8.09-8.38(\mathrm{~m}, 6 \mathrm{HM}+6 \mathrm{Hm}), 8.66-8.79(3 \mathrm{HM}+3 \mathrm{Hm}), 9.29$ $(\mathrm{dd}, J=1.5 \mathrm{~Hz}, J=4.9 \mathrm{~Hz}, 1 \mathrm{HM}+1 \mathrm{Hm}), 9.43(\mathrm{~d}, J=1.6 \mathrm{~Hz}, 1 \mathrm{HM}+1 \mathrm{Hm}) .{ }^{13} \mathrm{C}-\mathrm{NMR}\left(62.9 \mathrm{MHz}, 300 \mathrm{~K}_{1} \mathrm{CD}_{2} \mathrm{Cl}_{2}\right):(\delta, \mathrm{ppm})$ : 22.7 $M, 22.8 m, 23.4 m, 24.1 M, 26.0 M, 26.2 m, 26.4 M+m, 30.2 M, 30.7 m, 31.5 m, 31.9 M, 43.4 M, 44.6 m, 72.4 M, 72.8 m, 75.6 m$, 75.7M, 98.7M+m, 125.4M+m, 126.om, 126.1M, 126.2M, 126.5m, 127.1M, 127.7m, 128.7m, 128.8M, 129.4M, 129.5m, 130.7M, $130.8 m, 131.7 m, 131.9 M, 132.3 M, 132.4 m, 134.1 M+m, 135.2 M, 135.3 M, 135.4 m, 135.5 m, 139.0 M, 139.2 m, 151.1 M, 151.2 m$, 151.3M+m，171.5M，171.6M，171.7m，171.8m，171.9M，172.0m. HRMS (electrospray): Calculated for $\mathrm{C}_{28} \mathrm{H}_{31} \mathrm{~N}_{2} \mathrm{O}_{5}$ $\left(\mathrm{M}+\mathrm{H}^{+}\right): 475.2227$; found: 475.2240 Calculated for $\mathrm{C}_{28} \mathrm{H}_{30} \mathrm{~N}_{2} \mathrm{O}_{5} \mathrm{Na}\left(\mathrm{M}+\mathrm{Na}^{+}\right): 497.2047$; found: 497.2046 .

\section{(4R)-3-(1-naphthoyl)-4-((R)-(2-fluorophenyl)(hydroxy)methyl)-4-isobutyl-2,2-dimethyloxazolidin-5-one $5 a$}

Following the general procedure, (S)-3-(1-naphthoyl)-4-isobutyl-2,2-dimethyl-oxazolidin-5-one 1-A (100 mg, 0.307 mmol), 2-fluorobenzaldehyde (5 eq, $1.53 \mathrm{mmol}, 160 \mu \mathrm{L}$ ) and KHMDS (1.5 eq, $0.460 \mathrm{mmol}, 460 \mu \mathrm{L}(1 \mathrm{M}$ in THF)) in THF gave (4R)-3(1-naphthoyl)-4-((R)-(2-fluorophenyl)(hydroxy)methyl)-4-isobutyl-2,2-dimethyloxazolidin-5-one after 18 minutes. The crude product $(\mathrm{dr}=96 / 4)$ was then purified by column chromatography on silica gel (heptane/THF : 85/15) to give diastereomer 5 a (113 mg, 81\%, ee $=82 \%)$. HPLC analysis: $(\mathrm{S}, \mathrm{S})$ Whelk-O 1 , hexane/ethanol: $90 / 10,1 \mathrm{~mL} / \mathrm{min}, \mathrm{T}=25^{\circ} \mathrm{C}, \lambda=$ 
$222 \mathrm{~nm}$; retention times of racemic mixture: $10.6 \mathrm{~min}$. (minor) and $24.9 \mathrm{~min}$. (major) $e e=82 \%$ (minor diastereomer 12.4 min. (minor) and $16.4 \mathrm{~min}$. (major) ee $=86 \%$ ). ${ }^{1} \mathrm{H}-\mathrm{NMR}(300 \mathrm{~K}, \mathrm{CDCl})_{3}$ : Conformer ratio major $\left(M_{1}\right)$ : major $\left(M_{2}\right)$ : major $\left(M_{3}\right)$ :minor $(m)$ : 0.6:0.6:0.6: 0.1 (not described); $(\delta, \mathrm{ppm})$ : $0.85(\mathrm{~s}, 3 \mathrm{HM}), 0.87(\mathrm{~d}, J=6.0 \mathrm{~Hz}, 3 \mathrm{HM}), 0.98(\mathrm{~d}, J=7.3 \mathrm{~Hz}, 3 \mathrm{HM})$, 0.99 (bs, 6HM), $1.08(\mathrm{~d}, J=5.8 \mathrm{~Hz}, 3 \mathrm{HM}), 1.14(\mathrm{~d}, J=6.6 \mathrm{~Hz}, 3 \mathrm{HM}), 1.18(\mathrm{~s}, 3 \mathrm{HM}), 1.27(\mathrm{~d}, J=6.1 \mathrm{~Hz}, 3 \mathrm{HM}), 1.54(\mathrm{~s}, 3 \mathrm{HM})$, 1.80-1.67 (m, 4HM), 2.19-2.12 (m, 5HM), $\left.2.30(\mathrm{~s}, 3 \mathrm{HM}), 2.94(\mathrm{dd}, J=2.2 \mathrm{~Hz}, J=14.3 \mathrm{~Hz}, 1 \mathrm{HM})_{1}\right), 3.17\left(\mathrm{~d}, J=12.5 \mathrm{~Hz}, 1 \mathrm{HM} M_{2}+\right.$ $\left.1 \mathrm{H} M_{3}\right), 4.59\left(\mathrm{~d}, J=7.0 \mathrm{~Hz}, 1 \mathrm{HM}_{1}\right), 4.69\left(\mathrm{bs}, 1 \mathrm{H} M_{2}\right), 5.67\left(\mathrm{~d}, J=10.1 \mathrm{~Hz}, 1 \mathrm{H} M_{3}\right), 5.68\left(\mathrm{bs}, 1 \mathrm{H} M_{2}\right), 5.76\left(\mathrm{~d}, J=10.1 \mathrm{~Hz}, 1 \mathrm{HM} M_{3}\right)$, $\left.6.12(\mathrm{~d}, J=6.2 \mathrm{~Hz}, 1 \mathrm{H} \mathrm{M})_{1}\right) 6.64(\mathrm{t}, J=9.2 \mathrm{~Hz}, 1 \mathrm{HM}), 8.01-7.00(\mathrm{~m}, 32 \mathrm{HM}) .{ }^{13} \mathrm{C}-\mathrm{NMR}\left(75.5 \mathrm{MHz}, 300 \mathrm{~K}, \mathrm{CDCl}_{3}\right): 3$ conformers 1 major $(M)$ and 2 minor, same proportion $(m)(\delta, \mathrm{ppm}): 21.7 m, 22.7 M, 23.2 m, 24.0 m, 24.6 m * 3,24.9 m, 25.2 M, 25.7 M, 27.0 m$, 28.6m, 28.8M, 28.9M, 30.5m, 39.9m, 40.7M, 41.4m, 69.1m, 70.4m, 73.3m, 74.6m, 74.9M, 77.5M, 96.4M, 96.5m, 98.4m, $114.5 m(d, J=23 \mathrm{~Hz}), 115.7 m(d, J=23 \mathrm{~Hz}), 116.2 \mathrm{M}(\mathrm{d}, J=23 \mathrm{~Hz}), 123.4-134.1,159.6 \mathrm{~m}(\mathrm{~d}, J=249 \mathrm{~Hz}), 160.1 \mathrm{M}(\mathrm{d}, J=249 \mathrm{~Hz})$, $160.2 m(d, J=249 \mathrm{~Hz}), 168.7 m, 170.1 M, 170.3 m, 170.5 m, 171.1 M+m$. HRMS (electrospray): Calculated for $C_{27} \mathrm{H}_{29} \mathrm{FNO}_{4}$ $\left(\mathrm{M}+\mathrm{H}^{+}\right): 450.2075$; found: 450.2059 Calculated for $\mathrm{C}_{27} \mathrm{H}_{28} \mathrm{FNO}_{4} \mathrm{Na}\left(\mathrm{M}+\mathrm{Na}^{+}\right): 472.1895 ;$ found: 472.1879 .

(4R)-3-(1-naphthoyl)-4-((R)-(3-bromophenyl)(hydroxy)methyl)-2,2-dimethyl-4-(2-(methylthio)ethyl) oxazolidin-5-one 6a

Following the general procedure, (S)-3-(1-naphthoyl)-2,2-dimethyl-4-(2-(methylthio)ethyl)-oxazolidin-5-one 1-B (100mg, $0.290 \mathrm{mmol}), 3$-bromobenzaldehyde ( 5 eq, $1.45 \mathrm{mmol}, 170 \mu \mathrm{L}$ ) and KHMDS (1.5 eq, $0.430 \mathrm{mmol}, 430 \mu \mathrm{L}(1 \mathrm{M}$ in THF)) in THF gave (4R)-3-(1-naphthoyl)-4-((R)-(3-bromophenyl)(hydroxy)methyl)-2,2-dimethl-4-(2-(methylthio)ethyl)oxazolidin-5one after 10 minutes. The crude product (single diastereomer) was then purified by column chromatography on silica gel (PE/ethyl acetate : $100 \%$ to $70 / 30)$ to give diastereomer $6 a(100 \mathrm{mg}, 65 \%$, ee $=73 \%)$. Following the general procedure, $(S)$ 3-(1-naphthoyl)-2,2-dimethyl-4-(2-(methylthio)ethyl)-oxazolidin-5-one 1-B (10omg, 0.290 mmol), 3-bromobenzaldehyde (5 eq, $1.45 \mathrm{mmol}, 170 \mu \mathrm{L}$ ) and KHMDS (1.5 eq, $0.430 \mathrm{mmol}, 430 \mu \mathrm{L}(1 \mathrm{M}$ in THF)) in THF gave (4R)-3-(1-naphthoyl)-4-((R)-(3bromophenyl)(hydroxy)methyl)-2,2-dimethl-4-(2-(methylthio)ethyl)oxazolidin-5-one after 10 minutes. The crude product (single diastereomer) was then purified by column chromatography on silica gel (PE/ethyl acetate : $100 \%$ to $70 / 30$ ) to give diastereomer 6a (100 mg, 65\%, ee =73\%). HPLC analysis: $(S, S)$ Whelk-O 1, hexane/ethanol: 90/10 for 30 min. then with a gradient from $90 / 10$ to $80 / 20$ over $15 \mathrm{~min}$. and a step of $35 \mathrm{~min}$., $1 \mathrm{~mL} / \mathrm{min}, \mathrm{T}=25^{\circ} \mathrm{C}, \lambda=222 \mathrm{~nm}$; retention times of racemic mixture: $23.3 \mathrm{~min}$. (minor) and $26.6 \mathrm{~min}$. (major) ee $=73 \% .{ }^{1} \mathrm{H}-\mathrm{NMR}\left(250 \mathrm{MHz}, 300 \mathrm{~K}, \mathrm{CDCl}_{3}\right.$ ): Conformer ratio major $(M)$ :minor $(m)$ : 0.7: 0.3i $(\delta, \mathrm{ppm}): 0.44(\mathrm{~s}, 3 \mathrm{Hm}), 0.56(\mathrm{~s}, 3 \mathrm{HM}), 0.99(\mathrm{~s}, 3 \mathrm{HM}), 1.47(\mathrm{~s}, 3 \mathrm{Hm}), 2.25(\mathrm{~s}, 3 \mathrm{Hm}), 2.31(\mathrm{~s}, 3 \mathrm{HM}), 2.71-$ $3.03(\mathrm{~m}, 3 \mathrm{HM}+4 \mathrm{Hm}), 3.07-3.17(\mathrm{~m}, 1 \mathrm{HM}), 5.37(\mathrm{~d}, J=11.0 \mathrm{~Hz}, 1 \mathrm{HM}), 5.40(\mathrm{~d}, J=11.1 \mathrm{~Hz}, 1 \mathrm{Hm}), 6.67(\mathrm{~d}, J=11.1 \mathrm{~Hz}, 1 \mathrm{HM}), 6.71$ $(\mathrm{d}, J=11.1 \mathrm{~Hz}, 1 \mathrm{Hm}), 7.25-7.42\left(\mathrm{~m}, 3 \mathrm{HM}+{ }_{3} \mathrm{Hm}\right), 7.45-7.75(\mathrm{~m}, 6 \mathrm{HM}+6 \mathrm{Hm}), 7.86-7.99(\mathrm{~m}, 2 \mathrm{HM}+2 \mathrm{Hm}) .{ }^{13} \mathrm{C}-\mathrm{NMR}(100.0$ $\left.\mathrm{MHz}, 300 \mathrm{~K}, \mathrm{CDCl}_{3}\right): 3$ conformers $M+2 m(\delta, \mathrm{ppm}): 14.6 m, 15.5 m, 15.6 \mathrm{M}, 26.2 m, 27.0 m, 28.3 M+m, 28.7 m, 28.4 M+m, 28.9 M$, 30.4m, 32.4m, 32.9M, 33.1m, 56.5 M+2m, 75.4M, 75.6m, 76.1m, 96.7M, 96.8m, 98.2m, 123.2-133.7, 137.3m, 142.8m 142.9M, 169.9M, 170.3m*2, 170.6m, 171.2m, 171.5M. HRMS (electrospray): Calculated for $\mathrm{C}_{26} \mathrm{H}_{27} \mathrm{BrNO}_{4} \mathrm{~S}\left(\mathrm{M}+\mathrm{H}^{+}\right): 528.0839$; found: 528.0823 Calculated for $\mathrm{C}_{26} \mathrm{H}_{26} \mathrm{BrNNaO}_{4} \mathrm{~S}\left(\mathrm{M}+\mathrm{Na}^{+}\right)$: 550.0658 ; found: 550.0645 .

(4R)-3-(1-naphthoyl)-4-((R)-(2-bromophenyl)(hydroxy)methyl)-2,2-dimethyl-4-(2-methylthio)ethyl)oxazolidin-5-one 7a Following the general procedure, (S)-3-(1-naphthoyl)-2,2-dimethyl-4-(2-(methylthio)ethyl)-oxazolidin-5-one 1-B (100 mg, $0.290 \mathrm{mmol}), 2$-bromobenzaldehyde (5 eq, $1.45 \mathrm{mmol}, 170 \mu \mathrm{L}$ ) and KHMDS (1.5 eq, $0.430 \mathrm{mmol}, 430 \mu \mathrm{L}(1 \mathrm{M}$ in THF)) in THF gave (4R)-3-((R)1-naphthoyl)-4-((2-bromophenyl)hydroxy)methyl)-2,2-dimethyl-4-(2-methylthio)ethyl)oxazolidin-5one after 12 minutes. The crude product (single diastereomer) was then purified by column chromatography on silica gel (PE/ethyl acetate : $100 \%$ to 70/30) to give diastereomer 7 a (110 mg, 72\%, ee $=60 \%$ ). HPLC analysis: (S, S) Whelk-O 1, hexane/ethanol: $88 / 12$ for $30 \mathrm{~min}$. then with a gradient from $88 / 12$ to $80 / 20$ over $15 \mathrm{~min}$. and a step of $40 \mathrm{~min} ., 1 \mathrm{~mL} / \mathrm{min}, \mathrm{T}=$ $25^{\circ} \mathrm{C}, \lambda=222 \mathrm{~nm}$; retention times of racemic mixture: $15.5 \mathrm{~min}$. (minor) and $41.5 \mathrm{~min}$. (major) ee $=60 \%$ (minor diastereomer $11.9 \mathrm{~min}$. (minor) and $25.5 \mathrm{~min}$. (major) - other trials). ${ }^{1} \mathrm{H}-\mathrm{NMR}$ (300 $\mathrm{MHz}_{1} 300 \mathrm{~K}, \mathrm{CDCl}_{3}$ ): Conformer ratio major $(M)$ :minor $1\left(m_{1}\right)$ :minor $2\left(m_{2}\right): 0.4: 0.3: 0.2 ;(\delta, p p m): 1.00\left(s_{1} 3 \mathrm{Hm}_{1}\right), 1.19\left(\mathrm{~s}, 3 \mathrm{H} m_{1}\right), 1.25\left(\mathrm{~s}, 3 \mathrm{H} m_{2}\right), 1.27\left(\mathrm{~s}, 3 \mathrm{H} m_{2}\right)$, 
$2.02(\mathrm{~s}, 3 \mathrm{HM}), 2.03\left(\mathrm{~s}, 3 \mathrm{H} m_{1}\right), 2.06\left(\mathrm{~s}, 3 \mathrm{H} m_{2}\right), 2.19(\mathrm{~s}, 3 \mathrm{HM}), 2.28(\mathrm{~s}, 3 \mathrm{HM}), 2.37-2.88\left(\mathrm{~m}_{3} 3 \mathrm{HM}+3 \mathrm{H} m_{1}+3 \mathrm{H} m_{2}\right), 3.27-3.50(\mathrm{~m}$, $\left.1 \mathrm{HM}+1 \mathrm{Hm}_{1}+1 \mathrm{Hm}_{2}\right), 4.86\left(\mathrm{~d}, J=7.3 \mathrm{~Hz}, 1 \mathrm{Hm} m_{1}\right), 4.96(\mathrm{~d}, J=2.0 \mathrm{~Hz}, 1 \mathrm{HM}), 6.05\left(\mathrm{~d}, J=7.1 \mathrm{~Hz}, 1 \mathrm{Hm} m_{1}\right), 6.63(\mathrm{~d}, J=3.2 \mathrm{~Hz}$, $\left.1 \mathrm{H} m_{2}\right), 6.97-7.04(\mathrm{~m}, 1 \mathrm{HM}), 7.13-7.25\left(\mathrm{~m}, 1 \mathrm{H} M+1 \mathrm{H} m_{1}+2 \mathrm{H} m_{2}\right), 7.36-7.66\left(\mathrm{~m}, 6 \mathrm{HM}+6 \mathrm{H} m_{1}+6 \mathrm{H} m_{2}\right), 7.24-7.36(\mathrm{~m}, 1 \mathrm{HM}+$ $\left.{ }_{1} \mathrm{Hm}_{1}+1 \mathrm{Hm}_{2}\right), 7.85-7.98\left(3 \mathrm{HM}+{ }_{3} \mathrm{Hm}_{1}+{ }_{3} \mathrm{Hm}_{2}\right) .{ }^{13} \mathrm{C}-\mathrm{NMR}\left(100.0 \mathrm{MHz}, 300 \mathrm{~K}, \mathrm{CDCl}_{3}\right):(\delta, \mathrm{ppm}): 15.3 m_{21} 15.4 M+m_{11} 24.8 M_{1}$ $27.2 M_{1} 28.1 m_{21} 28.6 m_{11} 28.7 M_{1} 28.9 m_{11} 29.0 m_{11} 29.4 m_{21} \quad 30.3 m_{21} 30.6 m_{21} 32.2 m_{11} 33.1 M_{1} 71.8 m_{11} 72.3 m_{21} 73.7 M_{1} 74.1 m_{21}$ $74.2 M_{1} 74.3 m_{11} 96.5 M_{1} 98.4 m_{1}+m_{21} 123.2-134.2,135.4 m_{21} 137.6 M_{1} 138.5 m_{21} 139.2 m_{11} 168.5 m_{11} 169.0 M_{1} 169.4 m_{21} 169.5 M_{1}$ $170.3 m_{1}, 170.4 m_{2}$. HRMS (electrospray): Calculated for $\mathrm{C}_{26} \mathrm{H}_{27} \mathrm{BrNO}_{4} \mathrm{~S}\left(\mathrm{M}+\mathrm{H}^{+}\right)$: 528.0839 ; found: 528.0829 Calculated for $\mathrm{C}_{26} \mathrm{H}_{26} \mathrm{BrNNaO}_{4} \mathrm{~S}\left(\mathrm{M}+\mathrm{Na}^{+}\right)$: 550.0658 ; found: 550.0647 .

\section{(4R)-3-(1-naphthoyl)-4-(hydroxy(pyridin-2-yl)methyl)-2,2-dimethyl-4-(2-(methylthio)ethyl) oxazolidin-5-one 8}

Following the general procedure, (S)-3-(1-naphthoyl)-2,2-dimethyl-4-(2-(methylthio)ethyl)-oxazolidin-5-one 1-B (10omg, $0.290 \mathrm{mmol}$ ), 2-pyridinecarboxaldehyde ( 5 eq, $1.45 \mathrm{mmol}, 140 \mu \mathrm{L}$ ) and KHMDS (1.5 eq, $0.430 \mathrm{mmol}, 430 \mu \mathrm{L}(1 \mathrm{M}$ in THF)) in THF gave (4R)-3-(1-naphthoyl)-4-((R)-hydroxy(pyridin-2-yl)methyl)-2,2-dimethyl-4-(2-methylthio)ethyl)oxazolidin-5-one after 15 minutes. The crude product $(\mathrm{dr}=15 / 85)$ was then purified by column chromatography on silica gel (PE/ethyl acetate/ $\mathrm{Et}_{3} \mathrm{~N}: 8 \mathrm{o} / 20 / 1 \%$ to $\left.60 / 40 / 1 \%\right)$ to give minor diastereomer $8 \mathrm{a}(4 \mathrm{mg}, 3 \%$, ee $=82 \%)$ and major diastereomer $8 \mathrm{~b}(85$ mg, $65 \%$, ee $=97 \%)$. HPLC analysis: Chiralpack AD-H, hexane/ethanol: 95/5, $1 \mathrm{~mL} / \mathrm{min}, \mathrm{T}=38^{\circ} \mathrm{C}, \lambda=222 \mathrm{~nm}$; retention times of racemic mixture: $62.1 \mathrm{~min}$. (minor) and $67.8 \mathrm{~min}$. (major) $e e=97 \%$ (isolated with ee $>99 \%$ ) (minor diastereomer $47.6 \mathrm{~min}$. (minor) and $56.8 \mathrm{~min}$. (major) $e e=82 \%$ ). Minor diastereomer $8 \mathrm{a}-{ }^{1} \mathrm{H}-\mathrm{NMR}\left(400 \mathrm{MHz}, 300 \mathrm{~K}, \mathrm{CDCl}_{3}\right)$ : Conformer ratio major $(M)$ :minor $(m)$ : 1.0: 0.5i $(\delta, \mathrm{ppm}): 0.87(\mathrm{~s}, 3 \mathrm{HM}), 0.97(\mathrm{~s}, 3 \mathrm{Hm}), 1.15(\mathrm{~m}, 3 \mathrm{Hm}), 1.74(\mathrm{~s}, 3 \mathrm{HM}), 2.25(\mathrm{~s}, 3 \mathrm{HM}), 2.30(\mathrm{~s}$, $3 \mathrm{Hm}), 2.37-2.47(\mathrm{~m}, 2 \mathrm{Hm}), 2.56-2.67(\mathrm{~m}, 1 \mathrm{Hm}), 2.98-3.11(\mathrm{~m}, 4 \mathrm{HM}), 3.15-3.34(\mathrm{~m}, 1 \mathrm{Hm}), 5.53(\mathrm{~d}, J=11.0 \mathrm{~Hz}, 1 \mathrm{Hm}), 5.57(\mathrm{~d}, J=$ $11.7 \mathrm{~Hz}, 1 \mathrm{HM}), 6.04(\mathrm{~d}, J=8.4 \mathrm{~Hz}, 1 \mathrm{HM}), 6.44(\mathrm{~d}, J=11.7 \mathrm{~Hz}, 1 \mathrm{Hm}), 6.51(\mathrm{~d}, J=11.9 \mathrm{~Hz}, 1 \mathrm{HM}), 6.62(\mathrm{~d}, J=6.2 \mathrm{~Hz}, 1 \mathrm{Hm}), 7.07-$ $7.13(\mathrm{~m}, 1 \mathrm{HM}), 7.31-7.98(\mathrm{~m}, 8 \mathrm{HM}+9 \mathrm{Hm}), 8.57-8.60(\mathrm{~m}, 1 \mathrm{H} M), 8.66-8.69(\mathrm{~m}, 1 \mathrm{Hm}) .{ }^{13} \mathrm{C}-\mathrm{NMR}(100.0 \mathrm{MHz}, 300 \mathrm{~K}, \mathrm{CDCl}):(\delta$, ppm) : 15.6M, 15.7m, 27.3M, 28.0M, 28.1m, 28.6m, 29.7m, 30.4M, 33.6m, 34.5M, 72.6M, 73.3m, 74.9M, 76.1m, 96.2M+m, $121.2 m, 121.4 M, 122.8 M, 123.0 m, 124.0 M+m, 124.4 M, 124.5 m, 124.7 M, 125.3 m, 126.5 M, 126.8 m, 127.1 M, 127.7 m, 128.3 M$, $128.7 m, 129.4 m, 130.0 M, 130.2 M+m, 132.7 m, 133.1 M+m, 133.2 M, 136.9 M+m, 148.3 M, 148.6 m, 160.1 m, 160.2 M, 169.6 M$, 170.0m, 174.4M, 170.5m. HRMS (electrospray): Calculated for $\mathrm{C}_{25} \mathrm{H}_{27} \mathrm{~N}_{2} \mathrm{O}_{4} \mathrm{~S}\left(\mathrm{M}+\mathrm{H}^{+}\right)$: 451.1686; found: 451.1684 Calculated for $\mathrm{C}_{25} \mathrm{H}_{26} \mathrm{~N}_{2} \mathrm{NaO}_{4} \mathrm{~S}\left(\mathrm{M}+\mathrm{Na}^{+}\right.$): 473.1505; found: 473.1503. Major diastereomer 8b - ${ }^{1} \mathrm{H}-\mathrm{NMR}\left(360 \mathrm{MHz}, 300 \mathrm{~K}, \mathrm{C}_{6} \mathrm{D}_{6}\right.$ ): Conformer ratio major $(M)$ :minor $(m)$ : 1.0: $0.5 ;(\delta, p p m): 0.83(\mathrm{~s}, 3 \mathrm{Hm}), 0.93(\mathrm{~s}, 3 \mathrm{HM}), 1.22(\mathrm{~m}, 3 \mathrm{H} M+3 \mathrm{Hm}), 2.04(\mathrm{~s}, 3 \mathrm{Hm})$, $2.10(\mathrm{~s}, 3 \mathrm{HM}), 2.78-2.91(\mathrm{~m}, 3 \mathrm{Hm}), 2.95-3.15(\mathrm{~m}, 3 \mathrm{HM}), 3.52-3.63(\mathrm{~m}, 1 \mathrm{Hm}), 3.70-3.80(\mathrm{~m}, 1 \mathrm{HM}), 5.33(\mathrm{~d}, J=8.4 \mathrm{~Hz}, 1 \mathrm{HM})$, $5.35(\mathrm{~d}, J=8.3 \mathrm{~Hz}, 1 \mathrm{Hm}), 5.69(\mathrm{~d}, J=8.4 \mathrm{~Hz}, 1 \mathrm{HM}), 6.04(\mathrm{~d}, J=8.3 \mathrm{~Hz}, 1 \mathrm{Hm}), 6.61-6.72(\mathrm{~m}, 1 \mathrm{HM}+1 \mathrm{Hm}), 7.02-7.10(\mathrm{~m}, 2 \mathrm{HM}+$ $2 \mathrm{Hm}), 7.13-7.23(\mathrm{~m}, 2 \mathrm{HM}+3 \mathrm{Hm}), 7.24-7.36(\mathrm{~m}, 1 \mathrm{HM}+1 \mathrm{Hm}), 7.44(\mathrm{~d}, J=6.8 \mathrm{~Hz}, 1 \mathrm{HM}), 7.53-7.74(\mathrm{~m}, 2 \mathrm{HM}+2 \mathrm{Hm}), 7.96$ (bs, $\left.{ }_{1} \mathrm{HM}\right), 8.07(\mathrm{bs}, 1 \mathrm{Hm}), 8.30(\mathrm{~d}, J=3.9 \mathrm{~Hz}, 1 \mathrm{HM}), 8.40(\mathrm{~d}, J=3.7 \mathrm{~Hz}, 1 \mathrm{Hm}) .{ }^{1} \mathrm{H}-\mathrm{NMR}\left(400 \mathrm{MHz}, 300 \mathrm{~K}, \mathrm{CDCl}_{3}\right)$ : Conformer ratio major $(M)$ :minor $(m)$ : 0.7: 0.3; $(\delta, \mathrm{ppm}): 0.87(\mathrm{~s}, 3 \mathrm{Hm}), 1.11(\mathrm{~s}, 3 \mathrm{HM}), 1.28(\mathrm{~m}, 3 \mathrm{HM}), 1.51(\mathrm{~s}, 3 \mathrm{Hm}), 2.21(\mathrm{~s}, 3 \mathrm{Hm}), 2.26(\mathrm{~s}$, $3 \mathrm{HM}), 2.56-2.651(\mathrm{~m}, 3 \mathrm{Hm}), 2.70-2.83(\mathrm{~m}, 3 \mathrm{HM}), 3.20-3.30(\mathrm{~m}, 1 \mathrm{Hm}), 3.40-3.50(\mathrm{~m}, 1 \mathrm{H} M), 5.03$ (bs $1 \mathrm{HM}+1 \mathrm{Hm}), 5.46$ (bs, $1 \mathrm{HM}), 5.71(\mathrm{bs}, 1 \mathrm{Hm}), 7.26-7.93(\mathrm{~m}, 10 \mathrm{HM}+10 \mathrm{Hm}), 8.60-8.67(\mathrm{~m}, 1 \mathrm{HM}+1 \mathrm{Hm}) .{ }^{13} \mathrm{C}-\mathrm{NMR}(100.0 \mathrm{MHz}, 300 \mathrm{~K}, \mathrm{CDCl}):(\delta$, ppm) : $15.5 M+m, 28.4 m, 29.0 M, 29.6 m, 29.7 M * 2,30.5 m, 31.5 m, 32.4 M, 72.3 m, 73.2 M, 75.3 M+m, 96.7 M+m, 123.3 M, 123.6 m$, $123.8 \mathrm{M}, 123.9 \mathrm{~m}, 124.1 \mathrm{~m}, 124.2 \mathrm{M}, 124.8 \mathrm{M}, 125.4 \mathrm{M}, 125.6 \mathrm{~m}, 125.7 \mathrm{~m}, 126.4 \mathrm{~m}, 126.6 \mathrm{M}, 126.7 \mathrm{~m}, 127.4 \mathrm{M}, 128.4 \mathrm{~m}, 128.7 \mathrm{M}$ ， 129.8m, 129.9M, 130.0m, 130.2M, 133.3m, 133.4M, 133.8M, 134.1m, 136.6M+m, 148.9M+m, 157.2M, 158.0m, 169.1m, 169.3 $M_{1}$ 171.4M, 172.om. HRMS (electrospray): Calculated for $\mathrm{C}_{25} \mathrm{H}_{27} \mathrm{~N}_{2} \mathrm{O}_{4} \mathrm{~S}\left(\mathrm{M}+\mathrm{H}^{+}\right)$: 451.1686; found: 451.1672 Calculated for $\mathrm{C}_{25} \mathrm{H}_{26} \mathrm{~N}_{2} \mathrm{NaO}_{4} \mathrm{~S}\left(\mathrm{M}+\mathrm{Na}^{+}\right)$: 473.1505 ; found: 473.1500 .

(4R)-3-(1-naphthoyl)-4-((R)-(2-fluorophenyl)(hydroxy)methyl)-2,2-dimethyl-4-(2-(methylthio)ethyl) oxazolidin-5-one 9a

Following the general procedure, (S)-3-(1-naphthoyl)-2,2-dimethyl-4-(2-(methylthio)ethyl)-oxazolidin-5-one 1-B (10omg, $0.290 \mathrm{mmol}$ ), 2-fluorobenzaldehyde ( $5 \mathrm{eq}, 1.45 \mathrm{mmol}, 180 \mu \mathrm{L}$ ) and KHMDS (1.5 eq, $0.430 \mathrm{mmol}, 430 \mu \mathrm{L}(1 \mathrm{M}$ in THF)) in THF 
gave (4R)-3-(1-naphthoyl)-4-((R)-(2-fluorophenyl)(hydroxy)methyl)-2,2-dimethyl-4-(2-(methylthio)ethyl) oxazolidin-5-one after 18 minutes. The crude product (single diastereomer) was then purified by column chromatography on silica gel (heptane/THF : $90 / 10$ to 75/25) to give one diastereomer 9a (135 mg, 99\%, ee $=85 \%$ ). HPLC analysis: (S, S) Whelk-O 1 , hexane/ethanol $88 / 12$ for $30 \mathrm{~min}$. then with a gradient from $88 / 12$ to $80 / 20$ over $15 \mathrm{~min}$. and a step of $40 \mathrm{~min}$., $1 \mathrm{~mL} / \mathrm{min}, \mathrm{T}=$ $25^{\circ} \mathrm{C}, \lambda=222 \mathrm{~nm}$; retention times of racemic mixture: $15.8 \mathrm{~min}$. (minor) and $29.8 \mathrm{~min}$. (major) ee $=85 \%$ (minor diastereomer $11.9 \mathrm{~min}$. and $25.6 \mathrm{~min}$. from racemic). ${ }^{1} \mathrm{H}-\mathrm{NMR}\left(400 \mathrm{MHz}, 300 \mathrm{~K}, \mathrm{CDCl}_{3}\right.$ ): Conformer ratio major $(M)$ : $\operatorname{minor}$ $(m): 0.6: 0.3 ;(\delta, p p m): 0.75(\mathrm{~s}, 3 \mathrm{HM}), 0.78(\mathrm{~s}, 3 \mathrm{Hm}), 0.98(\mathrm{~s}, 3 \mathrm{HM}), 1.52(\mathrm{~s}, 3 \mathrm{Hm}), 2.20(\mathrm{~s}, 3 \mathrm{Hm}), 2.32(\mathrm{~s}, 3 \mathrm{HM}), 2.54-2.63(\mathrm{~m}$, $1 \mathrm{Hm}), 2.72-3.08(\mathrm{~m}, 3 \mathrm{Hm}+4 \mathrm{HM}), 5.28(\mathrm{~d}, J=9.4 \mathrm{~Hz}, 1 \mathrm{Hm}), 5.69(\mathrm{~d}, J=11.1 \mathrm{~Hz}, 1 \mathrm{HM}), 5.92(\mathrm{~d}, J=9.3 \mathrm{~Hz}, 1 \mathrm{Hm}), 6.16(\mathrm{~d}, J=$ 11.0 Hz, $1 \mathrm{HM}), 7.06-7.21(\mathrm{~m}, 2 \mathrm{HM}+2 \mathrm{Hm}), 7 \cdot 34-7.74(\mathrm{~m}, 6 \mathrm{HM}+6 \mathrm{Hm}), 7.06-7.95(\mathrm{~m}, 3 \mathrm{HM}+3 \mathrm{Hm}) .{ }^{13} \mathrm{C}-\mathrm{NMR}(100.0 \mathrm{MHz}, 300$ $\left.\mathrm{K}, \mathrm{CDCl}_{3}\right):(\delta, \mathrm{ppm}): 15.4 \mathrm{~m}, 15.6 \mathrm{M}, 28.2 \mathrm{~m}, 28.4 \mathrm{M}, 28.5 \mathrm{M}, 28.9 \mathrm{~m}, 29.0 \mathrm{M}, 30.4 \mathrm{~m}, 32.2 \mathrm{~m}, 32.8 \mathrm{M}, 70.6 \mathrm{~m}, 72.2 \mathrm{M}, 74.0 \mathrm{M}, 74.4 \mathrm{~m}$, $96.4 M+m, 115.7 m(d, J=22 \mathrm{~Hz}), 116.0 M(d, J=22 \mathrm{~Hz}), 124.1-133.4,159.6 \mathrm{M}+m(\mathrm{~d}, J=248 \mathrm{~Hz}), 169.0 \mathrm{M}, 169.5 m, 170.5 m$, 171.1M. HRMS (electrospray): Calculated for $\mathrm{C}_{26} \mathrm{H}_{27} \mathrm{FNO}_{4} \mathrm{~S}\left(\mathrm{M}+\mathrm{H}^{+}\right): 468.1639$; found: 468.1623 Calculated for $\mathrm{C}_{26} \mathrm{H}_{26} \mathrm{FNNaO}_{4} \mathrm{~S}\left(\mathrm{M}+\mathrm{Na}^{+}\right): 490.1459$; found: 490.1451. Following the general procedure, (S)-3-(1-naphthoyl)-2,2-dimethyl4-(2-(methylthio)ethyl)-oxazolidin-5-one 1-B (10omg, $0.290 \mathrm{mmol}$ ), 3-pyridinecarboxaldehyde (5 eq, $1.45 \mathrm{mmol}, 160 \mu \mathrm{L}$ ) and KHMDS (1 eq, $0.290 \mathrm{mmol}, 290 \mu \mathrm{L}(1 \mathrm{M}$ in THF)) in THF gave (4R)-3-(1-naphthoyl)-4-((R)-hydroxy(pyridin-3-yl)methyl)2,2-dimethyl-4-(2-(methylthio)ethyl) oxazolidin-5-one after 12 minutes. The crude product $(\mathrm{dr}=98 / 2)$ was then purified by column chromatography on silica gel (cyclohexane/ethyl acetate: 60/40 to 50/50) to give diastereomer $10 a$ (115 mg, $88 \%$, ee $=75 \%)$. HPLC analysis: : Chiralpack IC, hexane/ethanol: 90/10, $1 \mathrm{~mL} / \mathrm{min}, \mathrm{T}=25^{\circ} \mathrm{C}, \lambda=222 \mathrm{~nm}$; retention times of racemic mixture: $30.1 \mathrm{~min}$. (minor) and $34.0 \mathrm{~min}$. (major) ee =75\% (minor diastereomer $38.3 \mathrm{~min}$. (minor) and $41.3 \mathrm{~min}$. (major)). ${ }^{1} \mathrm{H}-\mathrm{NMR}\left(400 \mathrm{MHz}, 300 \mathrm{~K}, \mathrm{CDCl}_{3}\right)$ : Conformer ratio major $(M)$ :minor $(m)$ : 0.7: $0.3 ;(\delta, \mathrm{ppm}): 0.57(\mathrm{~s}, 3 \mathrm{HM}+3 \mathrm{Hm})$, $0.97(\mathrm{~s}, 3 \mathrm{HM}), 1.51(\mathrm{~s}, 3 \mathrm{Hm}), 2.19(\mathrm{~s}, 3 \mathrm{Hm}), 2.27(\mathrm{~s}, 3 \mathrm{HM}), 2.56-3.11(\mathrm{~m}, 4 \mathrm{HM}+4 \mathrm{Hm}), 5.41(\mathrm{~d}, J=10.4 \mathrm{~Hz}, 1 \mathrm{HM}), 5.59(\mathrm{~d}, J=8.5$ $\mathrm{Hz}, 1 \mathrm{Hm}), 6.23(\mathrm{~d}, J=9.4 \mathrm{~Hz}, 1 \mathrm{Hm}), 6.58(\mathrm{~d}, J=10.7 \mathrm{~Hz}, 1 \mathrm{HM}), 7.16(\mathrm{~d}, J=7.0 \mathrm{~Hz}, 1 \mathrm{HM}), 7.37-7.76(\mathrm{~m}, 6 \mathrm{HM}+6 \mathrm{Hm}), 7.82-7.94$ $(\mathrm{m}, 2 \mathrm{HM}+3 \mathrm{Hm}), 8.64-8.66(\mathrm{~m}, 1 \mathrm{HM}+1 \mathrm{Hm}), 8.72(\mathrm{bs}, 1 \mathrm{HM}), 8.79(\mathrm{bs}, 1 \mathrm{Hm}) .{ }^{13} \mathrm{C}-\mathrm{NMR}(100.0 \mathrm{MHz}, 300 \mathrm{~K}, \mathrm{CDCl}):(\delta, \mathrm{ppm})$ : 15.5m, 15.6M, 28.4M, 28.6M, 28.7m, 28.9M, 29.7m, 30.3m, 32.8m, 32.9M, 74.1m, 74.8m, 75.2M, 75.5M, 96.7M, 96.8m, $123.2 m, 123.5 M, 123.9 m, 124.1 M+m, 124.2 M, 125.2 M, 125.6 m, 126.9 m, 127.0 M, 127.5 m, 127.8 M, 128.6 m, 128.9 M, 129.5 M$, $129.8 m, 130.5 \mathrm{M}, 130.7 \mathrm{~m}, 132.4 \mathrm{M}, 132.8 \mathrm{~m}, 133.1 \mathrm{M}, 133.4 \mathrm{~m}, 134.7 \mathrm{M}, 135.1 \mathrm{~m}, 135.7 \mathrm{~m}, 136.0 \mathrm{M}, 148.5 \mathrm{M}, 148.7 \mathrm{~m}, 149.7 \mathrm{~m}$ ， 149.9M, 169.7M, 170.3m, 170.8m, 171.4M. HRMS (electrospray): Calculated for $\mathrm{C}_{25} \mathrm{H}_{27} \mathrm{~N}_{2} \mathrm{O}_{4} \mathrm{~S}\left(\mathrm{M}+\mathrm{H}^{+}\right)$: 451.1686; found: 451.1676 Calculated for $\mathrm{C}_{25} \mathrm{H}_{26} \mathrm{~N}_{2} \mathrm{NaO}_{4} \mathrm{~S}\left(\mathrm{M}+\mathrm{Na}^{+}\right)$: 473.1505 ; found: 473.1492

(4R)-3-(1-naphthoyl)-4-((R)-hydroxy(pyridin-2-yl)methyl)-4-isopropyl-2,2-dimethyloxazolidin-5-one 11b

Following the general procedure, (S)-3-(1-naphthoyl)-4-isopropyl-2,2-dimethyloxazolidin-5-one 1-C (100 mg, 0.320 mmol), 2-pyridinecarboxaldehyde ( 5 eq, $1.60 \mathrm{mmol}, 152 \mu \mathrm{L}$ ) and KHMDS (1.5 eq, $0.48 \mathrm{mmol}, 480 \mu \mathrm{L}(1 \mathrm{M}$ in THF)) in THF gave $(4 R)$ 3-(1-naphtoyl)-4-((R)-hydroxy(pyridin-2-yl)methyl)-4-isopropyl-2,2-dimethyloxazolidin-5-one after 18 minutes. The crude product $(\mathrm{dr}=7 / 93$ ) was then purified by column chromatography on silica gel (cyclohexane/ethyl acetate : $85 / 15$ to $30 / 70$ ) to give diastereomer (63 mg, 47\%, ee=90\%). HPLC analysis: Chiralpack AD-H, hexane/ethanol: $90 / 10,1 \mathrm{~mL} / \mathrm{min}, \mathrm{T}=30^{\circ} \mathrm{C}, \lambda=$ $222 \mathrm{~nm}$; retention times of racemic mixture: $12.9 \mathrm{~min}$. (minor) and $32.7 \mathrm{~min}$. (major) $e e=90 \%$ (minor diastereomer 19.2 min. (minor) and 39.2 min. (major) ee $=45 \%) .{ }^{1} \mathrm{H}-\mathrm{NMR}\left(400 \mathrm{MHz}, 300 \mathrm{~K}, \mathrm{CDCl}_{3}\right)$ : Conformer ratio major $(M)$ : $\operatorname{minor}(m)$ : 0.7 : 0.3i ( $\delta, \mathrm{ppm}): 0.94(\mathrm{~s}, 3 \mathrm{Hm}), 1.15(\mathrm{~s}, 3 \mathrm{HM}), 1.28(\mathrm{~s}, 3 \mathrm{HM}), 1.34(\mathrm{~d}, J=6.9 \mathrm{~Hz}, 3 \mathrm{HM}), 1.35(\mathrm{~d}, J=6.8 \mathrm{~Hz}, 3 \mathrm{Hm}), 1.50(\mathrm{~d}, J=7.1$ $\mathrm{Hz}, 3 \mathrm{Hm}), 1.51(\mathrm{~s}, 3 \mathrm{Hm}), 1.61(\mathrm{~d}, J=7.0 \mathrm{~Hz}, 3 \mathrm{HM}), 3.40$ (sept, $J=7.0 \mathrm{~Hz}, 1 \mathrm{Hm}), 3.70(\mathrm{sept}, J=7.0 \mathrm{~Hz}, 1 \mathrm{HM}), 5.74(\mathrm{~s}, 1 \mathrm{HM}), 6.07$ $(\mathrm{s}, 1 \mathrm{Hm}), 7.23-7.56(\mathrm{~m}, 7 \mathrm{HM}+6 \mathrm{Hm}), 7.67-7.80(\mathrm{~m}, 2 \mathrm{HM}+2 \mathrm{Hm}), 7.82-7.90(\mathrm{~m}, 2 \mathrm{HM}+3 \mathrm{Hm}), 8.56(\mathrm{~d}, J=4.6 \mathrm{~Hz}, 1 \mathrm{HM}), 8.63(\mathrm{~d}$, $J=4.8 \mathrm{~Hz}, 1 \mathrm{Hm}) .{ }^{13} \mathrm{C}-\mathrm{NMR}\left(100.0 \mathrm{MHz}, 300 \mathrm{~K}, \mathrm{CDCl}_{3}\right):(\delta, \mathrm{ppm}): 18.5 \mathrm{M}, 19.2 \mathrm{~m}, 19.9 m, 20.0 M, 29.0 M, 29.1 m, 29.7 M+m$, 29.8M, 31.3m, 72.3 $M, 73.9 m, 76.1 m, 77.7 M, 96.1 m, 96.2 M, 122.8 M, 123.5 m, 123.6 m, 123.8 M, 123.9 M+m, 125.2 M, 125.7 M$, $125.8 m, 125.9 m, 126.4 M, 126.5 m, 126.7 m, 127.2 M, 128.4 m, 128.5 M, 129.9 M+m, 130.0 M, 130.1 m, 133.4 M+m, 134.5 M+m$, 
136.5M+m, 148.1 M, 148.6m, 157.0M, 158.5m, 169.6M, 169.8m, 170.3M, 171.4m. HRMS (electrospray): Calculated for $\mathrm{C}_{25} \mathrm{H}_{27} \mathrm{~N}_{2} \mathrm{O}_{4}\left(\mathrm{M}+\mathrm{H}^{+}\right): 419.1965$; found: 419.1959 Calculated for $\mathrm{C}_{25} \mathrm{H}_{26} \mathrm{~N}_{2} \mathrm{NaO}_{4}\left(\mathrm{M}+\mathrm{Na}^{+}\right)$: 441.1785 ; found: 441.1777 .

((R)-3-(1-naphtoyl)-4-benzyl-2,2-dimethyl-5-oxooxazolidin-4-yl)(pyridin-2-yl)methyl acetate Ac-12

Following the general procedure, (S)-3-(1-naphthoyl)-4-benzyl-2,2-dimethyloxazolidin-5-one 1-D (200 mg, 0.556 mmol), 2 pyridinecarboxaldehyde (5 eq, $2.78 \mathrm{mmol}, 264 \mu \mathrm{L}$ ) and $\operatorname{KHMDS}(1.5 \mathrm{eq}, 0.834 \mathrm{mmol}, 834 \mu \mathrm{L}(1 \mathrm{M}$ in THF)) in THF (3 mL) gave (4R)-3-(1-naphthoyl)-4-benzyl-4-((2-pyridinyl)(hydroxy)methyl)-2,2-dimethyloxazolidin-5-one 12 after 12 minutes. Following the general procedure of acetylation, (4R)-3-(1-naphthoyl)-4-benzyl-4-(hydroxy(pyridin-2-yl)methyl)-2,2dimethyloxazolidin-5-one 12 (crude product - $452 \mathrm{mg}$ ), 4-(dimethylamino)pyridine (0.1 eq, $0.056 \mathrm{mmol}, 7 \mathrm{mg}$ ), acetic anhydride (5 eq, $2.78 \mathrm{mmol}, 260 \mu \mathrm{L})$, triethylamine (1.5 eq, $0.834 \mathrm{mmol}, 116 \mu \mathrm{L})$ in THF $(5.5 \mathrm{~mL})$ gave $((R)-3-(1$-naphthoyl)4-benzyl-2,2-dimethyl-5-oxooxazolidin-4-yl)(pyridin-2-l)methyl acetate after one night. The crude product (dr 56/44) was then purified by column chromatography on silica gel (PE/ethyl acetate : 80/20 to 70/30) then $\left(\mathrm{CH}_{2} \mathrm{Cl}_{2} /\right.$ ethyl acetate : 95/5 at 9o/10) to give two diastereomers Ac-12 (125 mg : first diastereomer Ac-12a 54 mg, ee = 29\%, mixture 15 mg, second diastereomer Ac-12b 56 mg, , ee = 29\%, 44\% in two steps). HPLC analysis: Chiralpack IC, hexane/ethanol: 90/10, 1 $\mathrm{mL} / \mathrm{min}, \mathrm{T}=25^{\circ} \mathrm{C}, \lambda=222 \mathrm{~nm}$; retention times of racemic mixture: $26.5 \mathrm{~min}$. (minor) and $28.2 \mathrm{~min}$. (major) ee $=29 \%$ (minor diastereomer $35.0 \mathrm{~min}$. (minor) and $55.6 \mathrm{~min}$. (major), ee = 29\%). First diastereomer Ac-12a - ${ }^{1} \mathrm{H}-\mathrm{NMR}(400 \mathrm{MHz}, 300 \mathrm{~K}$, $\left.\mathrm{CDCl}_{3}\right)$ : Conformer ratio major $(M)$ :minor $(m)$ : 0.7: 0.3; $(\delta, \mathrm{ppm})$ : $0.19(\mathrm{~s}, 3 \mathrm{HM}), 0.29(\mathrm{~s}, 3 \mathrm{Hm}), 0.33(\mathrm{~s}, 3 \mathrm{HM}), 0.76(\mathrm{~s}, 3 \mathrm{Hm})$, $2.28(\mathrm{~s}, 3 \mathrm{Hm}), 2.29(\mathrm{~s}, 3 \mathrm{HM}), 3.85(\mathrm{~d}, J=13.2 \mathrm{~Hz}, 1 \mathrm{HM}), 3.89(\mathrm{~d}, J=13.1 \mathrm{~Hz}, 1 \mathrm{Hm}), 4.21(\mathrm{~d}, J=13.3 \mathrm{~Hz}, 1 \mathrm{HM}), 4.39(\mathrm{~d}, J=13.4$ $\mathrm{Hz}, 1 \mathrm{Hm}), 6.81(\mathrm{~s}, 1 \mathrm{Hm}), 7.20(\mathrm{~d}, J=7.1 \mathrm{~Hz}, 1 \mathrm{HM}), 7.30-7.65(\mathrm{~m}, 10 \mathrm{HM}+12 \mathrm{Hm}), 7.69(\mathrm{~d}, J=7.8 \mathrm{~Hz}, 1 \mathrm{HM}), 7.77-7.86(\mathrm{~m}, 3 \mathrm{HM}$ $+3 \mathrm{Hm}), 8.41(\mathrm{~d}, J=8.2 \mathrm{~Hz}, 1 \mathrm{HM}), 8.76(\mathrm{~d}, J=3.9 \mathrm{~Hz}, 1 \mathrm{HM}+1 \mathrm{Hm}) .{ }^{13} \mathrm{C}-\mathrm{NMR}\left(100.0 \mathrm{MHz}, 300 \mathrm{~K}, \mathrm{CDCl}_{3}\right):(\delta, \mathrm{ppm}): 21.1 m$, $21.2 M, 27.5 M, 28.5 m, 29.0 M+m, 37.4 M, 39.3 m, 73.1 M, 73.4 m, 76.0 M, 76.2 m, 96.4 M, 96.8 m, 123.4 m, 123.7 M, 123.8 M$, $123.9 m, 124.3 M, 125.1 M ， 125.9 m ， 126.2 m ， 126.3 m ， 126.5 M+m, 126.8 M, 127.9 m, 128.0 M, 128.1 M ， 128.3 m ， 128.6 M$, $129.0 M * 2+m * 2,129.7 m, 129.8 M+m, 130.4 m, 131.2 M * 2+m * 2,131.4 M, 133.1 M, 133.2 m, 134.0 M, 134.1 m, 135.4 m, 135.7 M$, $136.9 m, 137.0 M, 149.3 M, 149.5 m, 156.0 m, 156.1 M ， 169.2 M ， 169.4 m ， 169.5 m ， 169.7 M ， 169.8 M, 170.5 m$. HRMS (electrospray): Calculated for $\mathrm{C}_{31} \mathrm{H}_{29} \mathrm{~N}_{2} \mathrm{O}_{5}\left(\mathrm{M}+\mathrm{H}^{+}\right)$: 509.2071; found:509.2060 Calculated for $\mathrm{C}_{31} \mathrm{H}_{28} \mathrm{~N}_{2} \mathrm{NaO}_{5}$ $\left(\mathrm{M}+\mathrm{Na}^{+}\right)$: 531.189o; found: 531.1878. Second diastereomer Ac-12b - ${ }^{1} \mathrm{H}-\mathrm{NMR}\left(400 \mathrm{MHz}, 300 \mathrm{~K}, \mathrm{CDCl}_{3}\right.$ ): Conformer ratio major $(M)$ :minor $(m): 0.8: 0.2 ;(\delta, p p m): 0.38(\mathrm{~s}, 3 \mathrm{Hm}), 0.51(\mathrm{~s}, 3 \mathrm{HM}), 1.02(\mathrm{~s}, 3 \mathrm{HM}), 1.38(\mathrm{~s}, 3 \mathrm{Hm}), 2.27(\mathrm{~s}, 3 \mathrm{H} M), 2.33(\mathrm{~s}$, $3 \mathrm{Hm}), 2.87(\mathrm{~d}, J=13.4 \mathrm{~Hz}, 1 \mathrm{HM}), 2.97(\mathrm{~d}, J=13.5 \mathrm{~Hz}, 1 \mathrm{Hm}), 4.40(\mathrm{~d}, J=13.4 \mathrm{~Hz}, 1 \mathrm{HM}), 4.48(\mathrm{~d}, J=13.8 \mathrm{~Hz}, 1 \mathrm{Hm}), 7.23-7.93$ $(\mathrm{m}, 16 \mathrm{HM}+17 \mathrm{Hm}), 8.73(\mathrm{~d}, J=4.1 \mathrm{~Hz}, 1 \mathrm{HM}) .{ }^{13} \mathrm{C}-\mathrm{NMR}\left(100.0 \mathrm{MHz}, 300 \mathrm{~K}, \mathrm{CDCl}_{3}\right):(\delta, \mathrm{ppm})$ only M described: 21.3, 28.3, $28.6,37.7,73.0,75.8,96.6,122.7,123.5,124.0,124.6,124.7,126.6,127.3,127.9,128.5,128.8 * 2,129.9,130.7,131.1 * 2,133.2$, $133.8,135.7,136.2,148.9,155.3,168.5,169.1,169.3$. HRMS (electrospray): Calculated for $\mathrm{C}_{31} \mathrm{H}_{29} \mathrm{~N}_{2} \mathrm{O}_{5}\left(\mathrm{M}+\mathrm{H}^{+}\right)$: 509.2071; found: 509.2051 Calculated for $\mathrm{C}_{31} \mathrm{H}_{28} \mathrm{~N}_{2} \mathrm{NaO}_{5}\left(\mathrm{M}+\mathrm{Na}^{+}\right)$: 531.1890 ; found: 531.1872 .

\section{(4R)-3-(1-naphthoyl)-4-benzyl-4-((R)-(2-fluorophenyl)(hydroxy)methyl)-2,2-dimethyloxazolidin-5-one 13a}

Following the general procedure, (S)-3-(1-naphthoyl)-4-benzyl-2,2-dimethyloxazolidin-5-one 1-D (100 mg, 0.278 mmol), 2 fluorobenzaldehyde (5 eq, $1.39 \mathrm{mmol}, 146 \mu \mathrm{L}$ ) and KHMDS (1.5 eq, $0.417 \mathrm{mmol}, 417 \mu \mathrm{L}(1 \mathrm{M}$ in THF)) in THF gave (4R)-3-(1naphthoyl)-4-benzyl-4-((R)-(2-fluorophenyl)(hydrox)methyl)-2,2-dimethyloxazolidin-5-one after 15 minutes. The crude product $(d r=98 / 2)$ was then purified by column chromatography on silica gel (PE/ethyl acetate : $100 \%$ to $80 / 20$ ) to give diastereomer $13 \mathrm{a}$ (70 mg, 52\%, ee = 34\%). HPLC analysis: Chiralpack IC, hexane/ethanol: 90/10, $1 \mathrm{~mL} / \mathrm{min}, \mathrm{T}=25^{\circ} \mathrm{C}, \lambda=$ $222 \mathrm{~nm}$; retention times of racemic mixture: $6.5 \mathrm{~min}$. (major) and $7.4 \mathrm{~min}$. (minor) ee $=34 \%$ (minor diastereomer $13.0 \mathrm{~min}$. and $15.3 \mathrm{~min}$. from racemic). ${ }^{1} \mathrm{H}-\mathrm{NMR}\left(400 \mathrm{MHz}, 300 \mathrm{~K}, \mathrm{CDCl}_{3}\right)$ : Conformer ratio major $(M)$ :minor $(m)$ : 1: 0.3; $(\delta, \mathrm{ppm})$ : 0.29 $(\mathrm{s}, 3 \mathrm{Hm}), 0.44(\mathrm{~s}, 3 \mathrm{HM}), 0.78(\mathrm{~s}, 3 \mathrm{HM}), 0.84(\mathrm{~s}, 3 \mathrm{Hm}), 3.26(\mathrm{~d}, J=13.7 \mathrm{~Hz}, 1 \mathrm{HM}), 3.57(\mathrm{~d}, J=14.0 \mathrm{~Hz}, 1 \mathrm{Hm}), 4.29(\mathrm{~d}, J=13.7$ $\mathrm{Hz}, 1 \mathrm{HM}), 4.48(\mathrm{~d}, J=7.3 \mathrm{~Hz}, 1 \mathrm{HM}), 4.53(\mathrm{~d}, J=14.2 \mathrm{~Hz}, 1 \mathrm{Hm}), 5.18(\mathrm{~d}, J=8.7 \mathrm{~Hz}, 1 \mathrm{Hm}), 5.92(\mathrm{~d}, J=8.8 \mathrm{~Hz}, 1 \mathrm{Hm}), 6.34(\mathrm{~d}, J=$ 7.2 Hz, $1 \mathrm{HM}), 7.11-7.20(\mathrm{~m}, 1 \mathrm{H} M+1 \mathrm{Hm}), 7.24-7.60(\mathrm{~m}, 11 \mathrm{HM}+11 \mathrm{Hm}), 7.69-7.92(\mathrm{~m}, 4 \mathrm{HM}+4 \mathrm{Hm}) .{ }^{13} \mathrm{C}-\mathrm{NMR}(100.0 \mathrm{MHz}$, 
$\left.300 \mathrm{~K}, \mathrm{CDCl}_{3}\right):(\delta, \mathrm{ppm}): 28.1 \mathrm{M}, 28.3 \mathrm{~m}, 28.6 \mathrm{M}, 28.7 m, 36.9 M, 38.5 m, 70.2 M, 72.9 m, 96.6 M+m, 115.6 \mathrm{M}(\mathrm{d}, J=22 \mathrm{~Hz}), 115.9 m$ $(d, J=22 \mathrm{~Hz}), 123.9 M+m, 124.0 M, 124.3 m, 125.3 M, 125.6 M, 125.8 m, 126.1 m, 126.5 M+m, 126.7 m, 126.8 M(d, J=15 \mathrm{~Hz})$, 127.0M, $127.2 m(\mathrm{~d}, J=14 \mathrm{~Hz}), 128.0 \mathrm{M}, 128.1 \mathrm{~m}, 128.4 \mathrm{M}, 128.7 m, 128.8 M * 2+m * 2,129.9 m, 130.1 M+m, 130.2 M, 130.3 M$ ， $130.4 m, 131.0 M * 2+m * 2,131.3 M, 133.3 m, 133.1 m, 133.3 M, 133.6 M+m, 135.3 m, 135.9 M, 160.1 M+m(d, J=248 \mathrm{~Hz}), 169.9 M$, 170.2M, 170.3m, 171.6m (one carbon $M$ and $m$ are under $\mathrm{CDCl}_{3}$ signal). HRMS (electrospray): Calculated for $\mathrm{C}_{30} \mathrm{H}_{27} \mathrm{FNO}_{4}$ $\left(\mathrm{M}+\mathrm{H}^{+}\right)$: 484.1919; found: 484.1908; Calculated for $\mathrm{C}_{30} \mathrm{H}_{26} \mathrm{FNNaO}_{4}\left(\mathrm{M}+\mathrm{Na}^{+}\right)$: 506.1738 ; found: 506.1727 .

\section{(R)-((R)-3-(1-naphtoyl)-4-isobutyl-2,2-dimethyl-5-oxooxazolidin-4-yl)(2-fluorophenyl)methyl acetate Ac-5a}

To a stirred solution of (4R)-3-(1-naphthoyl)-4-((R)-(2-fluorophenyl)(hydroxy)methyl)-4-isobutyl-2,2-dimethyloxazolidin-5one $5 \mathrm{a}$ (120 mg, $0.222 \mathrm{mmol}$ ) and 4-(dimethylamino)pyridine (0.01 eq, $0.0022 \mathrm{mmol}, 0.27 \mathrm{mg}$ ) in $\mathrm{CH}_{2} \mathrm{Cl}_{2}\left(2.2 \mathrm{~mL}\right.$ ) at $0^{\circ} \mathrm{C}$ were added acetic anhydride ( $1.2 \mathrm{eq}, 0.267 \mathrm{mmol}, 25 \mu \mathrm{L})$ and triethylamine (1.2 eq, $0.267 \mathrm{mmol}, 37 \mu \mathrm{L})$. The resulting mixture was stirred for $12 \mathrm{~h}$ at room temperature. The reaction was quenched by the addition of methanol. The mixture is washed with a $1 \mathrm{M} \mathrm{HCl}$ solution and water. The organic layer was dried over sodium sulfate, filtered, and then concentrated to give the crude product which was then purified through column chromatography on silica gel (PE/ethyl acetate: $100 \%$ to 8o/20) to give (R)-((R)-3-(1-naphthoyl)-4-isobutyl-2,2-dimethyl-5-oxooxazolidin-4-yl)(2-fluorophenyl)methyl acetate Ac-5a (75 mg, 69\%). ${ }^{1} \mathrm{H}-\mathrm{NMR}(250 \mathrm{MHz}, 300 \mathrm{~K}, \mathrm{CDCl})_{3}$ : Conformer ratio major $(M)$ : $\operatorname{minor}\left(m_{1}\right)$ : minor $\left(m_{2}\right)$ : 0.5:0.3:0.2; $(\delta, \mathrm{ppm})$ : $0.30\left(\mathrm{~d}, J=6.6 \mathrm{~Hz}, 3 \mathrm{Hm} m_{2}\right), 0.63\left(\mathrm{~d}, J=6.4 \mathrm{~Hz}, 3 \mathrm{Hm} m_{2}\right), 0.89(\mathrm{~d}, J=6.6 \mathrm{~Hz}, 3 \mathrm{HM}), 0.90\left(\mathrm{~s}, 3 \mathrm{H} m_{1}\right), 0.83-0.93\left(\mathrm{~m}_{1}, 1 \mathrm{Hm} m_{1}\right), 1.02(\mathrm{~d}, J$ $\left.=6.4 \mathrm{~Hz}, 3 \mathrm{Hm} m_{1}\right), 1.06(\mathrm{~d}, J=6.7 \mathrm{~Hz}, 3 \mathrm{HM}), 1.15\left(\mathrm{~d}, J=6.8 \mathrm{~Hz}, 3 \mathrm{Hm} m_{1}\right), 1.19(\mathrm{~s}, 3 \mathrm{HM}), 1.22\left(\mathrm{~s}, 3 \mathrm{H} m_{2}\right), 1.33-1.45\left(\mathrm{~m}_{1} 1 \mathrm{HM}+1 \mathrm{H} m_{2}\right)$, $1.67\left(\mathrm{~s}, 3 \mathrm{H} m_{2}\right), 1.69(\mathrm{~s}, 3 \mathrm{HM}), 1.77-1.89\left(\mathrm{~m}_{1} 1 \mathrm{H} m_{1}+1 \mathrm{H} m_{2}\right), 2.06\left(\mathrm{~s}, 3 \mathrm{H} m_{1}\right), 2.09-2.20\left(\mathrm{~m}, 1 \mathrm{H} M+1 \mathrm{H} m_{1}\right), 2.16(\mathrm{~s}, 3 \mathrm{HM}), 2.21(\mathrm{~s}$, $\left.3 \mathrm{H} m_{1}\right), 2.27\left(\mathrm{~s}, 3 \mathrm{Hm} m_{2}\right), 2.99(\mathrm{bd}, J=13.9 \mathrm{~Hz}, 1 \mathrm{HM}), 3.13\left(\mathrm{bd}, J=13.8 \mathrm{~Hz}, 1 \mathrm{Hm} m_{2}\right), 5.22\left(\mathrm{bs}, 1 \mathrm{H} m_{2}\right), 6.66\left(\mathrm{t}, J=9.4 \mathrm{~Hz}, 1 \mathrm{Hm} m_{2}\right)$, 6.80-7.78 $\left(\mathrm{m}_{1} 10 \mathrm{HM}+10 \mathrm{H} m_{1}+8 \mathrm{Hm}_{2}\right), 7.82-8.04\left(\mathrm{~m}, 2 \mathrm{HM}+2 \mathrm{Hm} m_{1}+2 \mathrm{Hm}_{2}\right) .{ }^{13} \mathrm{C}-\mathrm{NMR}(90 \mathrm{MHz}, 300 \mathrm{~K}, \mathrm{CDCl}):(\delta, \mathrm{ppm}): 21.5 M$, 21.8m, 23.0M, 24.0m, 24.6m, 24.8M, 27.0m, 27.1M, 28.9M, 29.6m, 30.1m, 30.7M, 39.2M+m, 71.2M, 72.1m, 96.2M, 98.2m, $115.5 M(d, J=22 \mathrm{~Hz}), 124.0-134.2,168.7 m, 168.8 M, 169.0 M+m, 170.0 m, 170.1 M$ (one carbon $M$ and $m$ are under $C D C l_{3}$ signal). HRMS (electrospray): Calculated for $\mathrm{C}_{29} \mathrm{H}_{31} \mathrm{FNO}_{5}\left(\mathrm{M}+\mathrm{H}^{+}\right)$: 492.2181 ; found: 492.2174 Calculated for $\mathrm{C}_{29} \mathrm{H}_{30} \mathrm{FNO} \mathrm{FNa}_{4}$ $\left(\mathrm{M}+\mathrm{Na}^{+}\right)$: 514.2000; found: 514.2003.

\section{(2R)-2-amino-2-((2-fluorophenyl)(hydroxy)methyl)-4-methylpentanoic acid hydrochloride 14}

Following the general procedure, ((R)-3-(1-naphthoyl)-4-isobutyl-2,2-dimethyl-5-oxooxazolidin-4-yl)(2fluorophenyl)methyl acetate Ac-5a (30 mg, $0.061 \mathrm{mmol})$, acetic acid (0.5 mL) and 6M HCl (1 mL) gave (2R)-2-amino-2-((2fluorophenyl)(hydroxy)methyl)-4-methylpentanoic acid hydrochloride $\mathbf{1 4}_{4}$ after $24 \mathrm{~h}$ (10 mg, 56\%). ${ }^{1} \mathrm{H}-\mathrm{NMR}(400 \mathrm{MHz}, 300$ $\left.\mathrm{K}, \mathrm{CD}_{3} \mathrm{OD}\right)(\delta, \mathrm{ppm}): 0.89(\mathrm{~d}, J=5.4 \mathrm{~Hz}, 3 \mathrm{H}), 0.99(\mathrm{~d}, J=5.4 \mathrm{~Hz}, 3 \mathrm{H}), 1.71-1.85(\mathrm{~m}, 2 \mathrm{H}), 2.03(\mathrm{~d}, J=8.8 \mathrm{~Hz}, 1 \mathrm{H}), 5.19(\mathrm{~s}, 1 \mathrm{H})$, $7.09(\mathrm{t}, J=9.5 \mathrm{~Hz}, 1 \mathrm{H}), 7.20(\mathrm{t}, J=7.1 \mathrm{~Hz}, 1 \mathrm{H}), 7.37(\mathrm{q}, J=6.9 \mathrm{~Hz}, 1 \mathrm{H}), 7.60(\mathrm{t}, J=7.0 \mathrm{~Hz}, 1 \mathrm{H}) .{ }^{13} \mathrm{C}-\mathrm{NMR}(100 \mathrm{MHz}, 300 \mathrm{~K}$, $\left.\mathrm{CD}_{3} \mathrm{OD}\right)(\delta, \mathrm{ppm}): 22.7,24.9,25.2,42.2,68.8,71.0,116.0(\mathrm{~d}, J=23 \mathrm{~Hz}), 125.1,127.0(\mathrm{~d}, J=14 \mathrm{~Hz}), 131.3,131.5,161.5(\mathrm{~d}, J=$ $244 \mathrm{~Hz}$ ), 171.2. HRMS (electrospray): Calculated for $\mathrm{C}_{13} \mathrm{H}_{19} \mathrm{FNO}_{3}\left(\mathrm{M}+\mathrm{H}^{+}\right)$: 256.1343; found: 256.1339 ; Calculated for $\mathrm{C}_{13} \mathrm{H}_{18} \mathrm{FNNaO}_{3}\left(\mathrm{M}+\mathrm{Na}^{+}\right): 278.1163$; found: 278.1157 .

\section{(2R)-2-amino-2-((R)-hydroxy(pyridin-3-yl)methyl)-4-methylpentanoic acid hydrochloride 15}

Following the general procedure, $(R)$-((R)-3-(1-naphthoyl)-4-isobutyl-2,2-dimethyl-5-oxooxazolidin-4-yl)(pyridin-3yl)methyl acetate Ac-4a (45 mg, $0.095 \mathrm{mmol})$, acetic acid $(0.5 \mathrm{~mL})$ and $6 \mathrm{M} \mathrm{HCl}(1 \mathrm{~mL})$ gave $(2 R)$-2-amino-2-((R)hydroxy(pyridin-3-yl)methyl)-4-methylpentanoic acid hydrochloride 15 after $24 \mathrm{~h}$ ( $26 \mathrm{mg}$, quantitative yield). ${ }^{1} \mathrm{H}-\mathrm{NMR}$ (400 $\left.\mathrm{MHz}, 300 \mathrm{~K}, \mathrm{CD}_{3} \mathrm{OD}\right)(\delta, \mathrm{ppm}): 0.90(\mathrm{~d}, J=6.5 \mathrm{~Hz}, 3 \mathrm{H}), 1.03(\mathrm{~d}, J=6.6 \mathrm{~Hz}, 3 \mathrm{H}), 1.69(\mathrm{dd}, J=9.4 \mathrm{~Hz}, J=14.3 \mathrm{~Hz}, 1 \mathrm{H}), 1.82-1.96$ $(\mathrm{m}, 1 \mathrm{H}), 2.21(\mathrm{dd}, J=3.1 \mathrm{~Hz}, J=14.3 \mathrm{~Hz}, 1 \mathrm{H}), 5.28(\mathrm{~s}, 1 \mathrm{H}), 8.14(\mathrm{dd}, J=5.1 \mathrm{~Hz}, J=7.9 \mathrm{~Hz}, 1 \mathrm{H}), 8.71(\mathrm{~d}, J=7.9 \mathrm{~Hz}, 1 \mathrm{H}), 8.90(\mathrm{~d}, J$ $=5.1 \mathrm{~Hz}, 1 \mathrm{H}), 8.96(\mathrm{~s}, 1 \mathrm{H}) .{ }^{13} \mathrm{C}-\mathrm{NMR}\left(100 \mathrm{MHz}, 300 \mathrm{~K}, \mathrm{CD}_{3} \mathrm{OD}\right)(\delta, \mathrm{ppm}): 22.3,24.8,25.1,43.2,68.1,73.8,127.9,140.9$, $142.7 * 2,147.2,171.0$. 


\section{Supplementary Material}

CCDC 2093028-2093030 \& 2094493 contain the supplementary crystallographic data for compounds 3b, Ac-5a, 8b and Ac12a. These data can be obtained free of charge from the Cambridge Crystallographic Data Centre via http://www.ccdc.cam.ac.uk/Communityl. Supporting information for this article is available on the WWW under http://dx.doi.org/10.1002/MS-number.

\section{Acknowledgements}

We thank the Marie Curie program for a IIF fellowship (post-doctoral fellowship to B.V., grant PIIF-GA-2011-300491). We also thank the synthesis support facility (Pôle Synthèse) at ICMMO for their help.

\section{Author Contribution Statement}

L.R. and B. V. performed the experiments and analyzed the data; R.G. was in charge of all the crystal analyses and D. G. of HPLC analyses. C.K. helped to write the paper. V.A. conceived and designed the experiments, analyzed the data and wrote the paper.

\section{References}

[1] J. F. de S. Daniel, E. R. Filho, 'Peptaibols of Trichoderma', Nat. Prod. Rep. 2007, 24, 1128-1141.

[2] S. H. Kang, S. Y. Kang, H.-S. Lee, A. J. Buglass, 'Total Synthesis of Natural tert-Alkylamino Hydroxy Carboxylic Acids', Chem. Rev. 2005, 105, 4537-4558.

[3] R. P. Hicks, 'Antibacterial and anticancer activity of a series of novel peptides incorporating cyclic tetra-substituted C $\alpha$ amino acids', Bioorg. Med. Chem. 2016, 24, 4056-4065

[4] J. H. Kim, S. Lee, S. Kim, 'Biomimetic Total Synthesis of (-)-Penibruguieramine A Using Memory of Chirality and Dynamic Kinetic Resolution', Angew. Chem. Int. Ed. 2015, 54, 10875-10878.

[5] T. Liu, N. Yan, H. Zhao, Z.-X. Wang, X.-G. Hu, 'Synthesis and antibacterial activity of 6( R )- and 6( S )-fluoropenibruguieramine As: Fluorine as a probe for testing the powerfulness of memory of chirality (MOC)', J. Flvor. Chem. 2018, 207, 18-23.

[6] C. Cativiela, M. Ordóñez, J. L. Viveros-Ceballos, 'Stereoselective synthesis of acyclic $\alpha, \alpha$-disubstituted $\alpha$-amino acids derivatives from amino acids templates', Tetrahedron 2020, 76, 130875.

[7] A. E. Metz, M. C. Kozlowski, 'Recent Advances in Asymmetric Catalytic Methods for the Formation of Acyclic $\alpha, \alpha-D i s u b s t i t u t e d ~ \alpha-$ Amino Acids', J. Org. Chem. 2015, 80, 1-7.

[8] J. Blesl, M. Trobe, F. Anderl, R. Breinbauer, G. A. Strohmeier, K. Fesko, 'Application of Threonine Aldolases for the Asymmetric Synthesis of $\alpha$-Quaternary $\alpha$-Amino Acids', Chem CatChem 2018, 10, 3453-3458.

[9] A. Ueda, M. Ikeda, T. Kasae, M. Doi, Y. Demizu, M. Oba, M. Tanaka, 'Synthesis of Chiral $\alpha$-Trifluoromethyl $\alpha, \alpha-D i s u b s t i t u t e d ~ \alpha-$ Amino Acids and Conformational Analysis of L-Leu-Based Peptides with (R)- or (S)- $\alpha$-Trifluoromethylalanine', ChemistrySelect 2020, $5,10882-10886$.

[10] G. Lupidi, A. Palmieri, M. Petrini, 'Enantioselective Catalyzed Synthesis of Amino Derivatives Using Electrophilic Open-Chain NActivated Ketimines', Adv. Synth. Catal. n.d., n/a, DOI 10.1002/adsc. 202100292.

[11] V. Alezra, T. Kawabata, 'Recent Progress in Memory Of Chirality (MOC): An Advanced Chiral Pool', Synthesis 2016, 48, $2997-3016$.

[12] T. Hardwick, N. Ahmed, 'Memory of Chirality as a Prominent Pathway for the Synthesis of Natural Products through Chiral Intermediates', ChemistryOpen 2018, 7, 484-487.

[13] S. Tan, F. Li, S. Park, S. Kim, 'Carbocyclization of Heterosubstituted Alkynes via the Memory of Chirality: Access to C $\alpha$-Substituted Proline Derivatives', J. Org. Chem. 2019, 84, 14436-14450.

[14] S. Tan, F. Li, S. Park, S. Kim, 'Memory of Chirality in Bromoalkyne Carbocyclization: Applications in Asymmetric Total Synthesis of Hasubanan Alkaloids', Org. Lett. 2019, 21, 292-295.

[15] S. Lee, M. Bae, J. In, J. H. Kim, S. Kim, 'Asymmetric Total Synthesis of Lepadiformine C Using Memory of Chirality in an Intramolecular Ester Enolate Michael Addition', Org. Lett. 2017, 19, 254-257.

[16] V. Veeraswamy, G. Goswami, S. Mukherjee, K. Ghosh, M. L. Saha, A. Sengupta, M. K. Ghorai, 'Memory of Chirality Concept in Asymmetric Intermolecular Michael Addition of $\alpha$-Amino Ester Enolates to Enones and Nitroalkenes', J. Org. Chem. 2018, 83, 11061115 .

[17] H. Ohtsuki, M. Takashima, T. Furuta, T. Kawabata, 'Direct asymmetric synthesis of $\alpha$-deuterated $\alpha$-amino acid derivatives from the parent $\alpha$-amino acids via memory of chirality', Tetrahedron Lett. 2018, 59, 1188-1191.

[18] K. Kasamatsu, T. Yoshimura, A. Mandi, T. Taniguchi, K. Monde, T. Furuta, T. Kawabata, ' $\alpha$-Arylation of $\alpha$-Amino Acid Derivatives with Arynes via Memory of Chirality: Asymmetric Synthesis of Benzocyclobutenones with Tetrasubstituted Carbon', Org. Lett. 2017, $19,352-355$. 
[19] K. Tomohara, K. Kasamatsu, T. Yoshimura, T. Furuta, T. Kawabata, 'Asymmetric Synthesis of Multisubstituted Dihydrobenzofurans by Intramolecular Conjugate Addition of Short-Lived C-O Axially Chiral Enolates', Chem. Pharm. Bull. (Tokyo) $2016,64,899-906$.

[20] T. Hardwick, R. Cicala, N. Ahmed, 'Memory of chirality in a room temperature flow electrochemical reactor', Sci. Rep. 2020, 10, 16627.

[21] J. H. Kim, Y. Chung, H. Jeon, S. Lee, S. Kim, 'Stereoselective Asymmetric Synthesis of Pyrrolidines with Vicinal Stereocenters Using a Memory of Chirality-Assisted Intramolecular SN2' Reaction', Org. Lett. 2020, 22, 3989-3992.

[22] L. Kolaczkowski, J. Barkalow, D. M. Barnes, A. Haight, W. Pritts, A. Schellinger, 'Synthesis of (R)-Boc-2-methylproline via a Memory of Chirality Cyclization. Application to the Synthesis of Veliparib, a Poly(ADP-ribose) Polymerase Inhibitor', J. Org. Chem. 2019, 84, 4837-4845.

[23] G. Vilé, G. Schmidt, S. Richard-Bildstein, S. Abele, 'Enantiospecific cyclization of methyl N-(tert-butoxycarbonyl)-N-(3chloropropyl)-D-alaninate to 2-methylproline derivative via "memory of chirality" in flow', J. Flow Chem. 2019, 9, 19-25.

[24] P. S. Mahajan, S. B. Mhaske, 'Silver-Mediated Oxidative Decarboxylative Intramolecular Asymmetric Radical Cyclization (Csp3Csp2) via Memory of Chirality: Access to Circumdatin Alkaloids', Org. Lett. 2018, 20, 2092-2095.

[25] M. Branca, S. Pena, R. Guillot, D. Gori, V. Alezra, C. Kouklovsky, 'Memory of Chirality of Tertiary Aromatic Amides: A Simple and Efficient Method for the Enantioselective Synthesis of Quaternary $\alpha$-Amino Acids', J. Am. Chem. Soc. 2009, 131, 10711-10718.

[26] M. Branca, D. Gori, R. Guillot, V. Alezra, C. Kouklovsky, 'Tertiary Aromatic Amide for Memory of Chirality: Access to Enantioenriched $\alpha$-Substituted Valine', J. Am. Chem. Soc. 2008, 130, 5864-5865.

[27] T. T. Mai, B. Viswambharan, D. Gori, C. Kouklovsky, V. Alezra, 'Memory of Chirality of Tertiary Aromatic Amide: Application to the Asymmetric Synthesis of (S)- $\alpha$-MethylDOPA', J. Org. Chem. 2012, 77, 8797-8801.

[28] A. Mambrini, D. Gori, C. Kouklovsky, H. Kim, J. Yoshida, V. Alezra, 'Memory of Chirality in a Flow-Based System: Enantioselective Synthesis of Quaternary $\alpha$-Amino Acids Using Flow Microreactors: Memory of Chirality in a Flow-Based System: Enantioselective Synthesis of Quaternary $\alpha$-Amino Acids Using Flow Microreactors', Eur. J. Org. Chem. 2018, 2018, 6754-6757.

[29] A. Mambrini, D. Gori, R. Guillot, C. Kouklovsky, V. Alezra, 'Oxidative coupling of enolates using memory of chirality: an original enantioselective synthesis of quaternary $\alpha$-amino acid derivatives', Chem. Commun. 2018, 54, 12742-12745.

[30] B. Viswambharan, D. Gori, R. Guillot, C. Kouklovsky, V. Alezra, 'Substrate Control in Enantioselective and Diastereoselective Aldol Reaction by Memory of Chirality: A Rapid Access to Enantiopure $\beta$-Hydroxy Quaternary $\alpha$-Amino Acids', Org. Lett. 2014, 16, 788-791.

[31] I. Zelocualtecatl-Montiel, F. García-Álvarez, J. R. Juárez, L. Orea, D. Gnecco, A. Mendoza, F. Chemla, F. Ferreira, O. Jackowski, D. M. Aparicio, A. Perez-Luna, J. L. Terán, 'Asymmetric Tandem Conjugate Addition-Aldol Condensation with N-Acryloyloxazolidines Derived from 2-Phenylglycinol', Asian J. Org. Chem. 2017, 6, 67-70.

[32] A. Saddiqa, A. R. Raza, D. StC. Black, N. Kumar, 'Chiron based synthesis of isocoumarins: reactivity of $\alpha$-substituted carboxylic acids', Tetrahedron Asymmetry 2014, 25, 736-743.

[33] T. T. Mai, M. Branca, D. Gori, R. Guillot, C. Kouklovsky, V. Alezra, 'Absolute Asymmetric Synthesis of Tertiary $\alpha$-Amino Acids', Angew. Chem. Int. Ed. 2012, 51, 4981-4984

[34] T. T. Mai, B. Viswambharan, D. Gori, R. Guillot, J.-V. Naubron, C. Kouklovsky, V. Alezra, 'Frozen Chirality of Tertiary Aromatic Amides: Access to Enantioenriched Tertiary $\alpha$-Amino Acid or Amino Alcohol without Chiral Reagent', Chem. - Eur. J. 2017, 23, 57875798. 